\title{
The Federal Rules of Civil Settlement
}

\author{
J. Maria Glover \\ Georgetown University Law Center, jmg338@georgetown.edu
}

This paper can be downloaded free of charge from:

https://scholarship.law.georgetown.edu/facpub/1875

https://ssrn.com/abstract=1958615

87 N.Y.U. L. Rev. 1713 (2012)

This open-access article is brought to you by the Georgetown Law Library. Posted with permission of the author. Follow this and additional works at: https://scholarship.law.georgetown.edu/facpub

Part of the Civil Procedure Commons 


\title{
ARTICLES
}

\section{THE FEDERAL RULES OF CIVIL SETTLEMENT}

\begin{abstract}
J. MARIA GLOVER*
The Federal Rules of Civil Procedure were originally based upon a straightforward model of adjudication: Resolve the merits of cases at trial and use pretrial procedures to facilitate accurate trial outcomes. Though appealing in principle, this model has little relevance today. As is now well known, the endpoint around which the Federal Rules were structured-trial-virtually never occurs. Today, the vast majority of civil cases terminate in settlement. This Article is the first to argue that the current litigation process needs a new regime of civil procedure for the world of settlement.
\end{abstract}

This Article begins by providing a systemic analysis of why the Federal Rules inadequately prevent settlement outcomes from being distorted relative to the underlying merits-as defined by reference to substantive law-of a given dispute. It then explains how the Federal Rules can actually amplify these distortions. Indeed, notwithstanding the well-worn adage that settlement occurs in the "shadow of the law," scholars have shown that non-merits factors exert significant influence on settlement outcomes. However, these insights have not been considered together and combined with a systemic focus on the ways in which the influence of these factors on settlement outcomes is actually a product of the basic structural features of the Federal Rules. This Article takes these next steps to explain that the "shadow of the law" that is cast on settlements is fading. Further, this Article discusses a new phenomenon in the current litigation environment-namely, that litigants' increased reliance on prior settlements as "precedent" for future settlement decisions may move settlement even further out of the "shadow of the law" and into the "shadow of settlement" itself.

This Article then traces these problems to three foundational assumptions underlying the Federal Rules of Civil Procedure, all of which have become outmoded

* Copyright (C) 2012 by J. Maria Glover, Associate Professor, Georgetown University Law Center. For their insightful comments, I would like to thank David Barron, Elizabeth Chamblee Burch, Nora Engstrom, John Goldberg, Derek Ho, William Hubbard, Samuel Issacharoff, Leslie Kendrick, Adam Levitin, Geoffrey Miller, Martha Minow, Robert Mnookin, Jonathan Molot, Eloise Pasachoff, David Shapiro, Charles Silver, Suzanna Sherry, Jay Tidmarsh, and workshop participants at the American University School of Law, Cardozo School of Law, Columbia Law School, Georgetown University Law Center, Harvard Law School, New York University School of Law, Temple Law School, UCLA School of Law, University of Alabama School of Law, University of California Berkeley School of Law, University of Chicago School of Law, University of Washington School of Law, and Wake Forest University School of Law. I am indebted to Richard Nagareda, who encouraged me to pursue this project. Will Dreher and Amanda Willis at Harvard Law School and Nacim Bouchita and Marc Werner at Georgetown University Law Center provided excellent research assistance. Thanks also to Nathan Foell, Vanessa Richardson, and the editors of the New York University Law Review for their careful work on this piece. 
in a world of settlement. In rethinking these assumptions, it provides a new conceptual account that contextualizes previously isolated procedural reform proposals as challenges to these foundational assumptions. It also explains how these reform efforts ought to be refined and extended with a specific view toward systematically redesigning the basic model and operation of the Federal Rules for a world of settlement. Lastly, it sets forth new proposals that seek to reorient current rules expressly toward the goal of aligning settlement outcomes with the merits of underlying claims.

What emerges is a new vision of procedure-one in which the application of pretrial procedural rules do not merely facilitate trial but are designed to provide litigants with guidance regarding the merits of claims and are used to align settlement outcomes more meaningfully with the dictates of the substantive law. In describing this vision, this Article lays the groundwork for the design of a new Federal Rules of Civil Settlement.

INTRODUCTION

I. Litigation Under the Federal RUles of Civil Procedure: The DISAPPEARANCE OF TRIALS AND THE RISE OF SETTLEMENT 106

II. The VAnishing Shadow of the LaW AND ThE Growing SHadow OF SETTLEMENT

A. The Vanishing Shadow of the Law

1. Overshadowed Shadows: Pretrial Procedures Inadequately Address the Impact of Non-merits Factors on Settlement Outcomes.

a. Litigation Costs

b. Informational Imbalances

c. Variance

2. Faint Shadows: Pretrial Procedures Fail To Provide

Parties with Robust Merits-Related Guidance for Settlement.

a. Pretrial Adjudicative Procedures Generate Limited Merits Guidance

b. Robust Merits Evaluation Occurs Too Late in the Litigation Process To Influence Settlement Outcomes

c. Pretrial Merits-Screening Procedures Sometimes Fail on Their Own Terms

d. Scarce Trials and Current Pretrial Managerial Judging Practices Do Not Cure These Problems ......131

B. Eclipsing the Shadow of the Law: Settlements in the Shadow of Settlement

III. TOWARD THE FEDERAL RULES OF CIVIL SETTLEMENT.

A. Redesigning Procedure for a World of Settlement by Reconsidering Core Assumptions of the Federal Rules

1. Rethinking the Assumption that Plenary Discovery 
Aligns Case Outcomes with the Merits

2. Rethinking the Assumption that the Proper Role of

Pretrial Adjudicative Mechanisms Is Limited to

Screening Out Meritless Cases

a. Harnessing Pleading-Stage Procedural

Mechanisms To Provide More Robust Merits-

Based Guidance

b. Creating Post-Pleading-Stage Mechanisms that

Provide Meaningful Merits-Based Guidance

3. Rethinking the Assumption that Procedural Rules Should Apply Uniformly and Transsubstantively to All

Cases.

B. A New Vision of Procedures Designed for a World of

Settlement

\section{INTRODUCTION}

The Federal Rules of Civil Procedure (Federal Rules), enacted in 1938, were designed to achieve a fundamental goal: to facilitate the resolution of cases on their merits. ${ }^{1}$ To accomplish that goal, the reformers behind the Federal Rules eschewed technical formalities in favor of a streamlined procedural system, one for which plenary truthseeking followed by trial was the "gold standard."2 However, federal

15 Charles Alan Wright \& Arthur R. Miller, Federal Practice and Procedure $§ 1182$ (3d ed. 2004) (stating that a basic philosophy of the Federal Rules is to facilitate a "determination of litigation on the merits"); see also Mark Herrmann, James M. Beck \& Stephen B. Burbank, Debate, Plausible Denial: Should Congress Overrule Twombly and Iqbal?, 158 U. PA. L. REV. PENNUMBRA 141, 148 (2009), http://www.pennumbra.com/debates/pdfs/PlausibleDenial.pdf ("The drafters of the Federal Rules objected to fact pleading because it ... too often cut[] off adjudication on the merits."); Jay Tidmarsh, Pound's Century, and Ours, 81 Notre DAmE L. Rev. 513, 527 (2006) (stating that one goal of the new procedural rules was "the resolution of cases on their substantive merits").

2 Arthur R. Miller, From Conley to Twombly to Iqbal: A Double Play on the Federal Rules of Civil Procedure, 60 DukE L.J. 1, 5 (2010) [hereinafter Miller, From Conley]; see also Tidmarsh, supra note 1, at 549 ("[0]ur procedural system is structured around the belief that a case will be resolved at a culminating, all-issues jury trial."). To be sure, the 1938 reformers were aware of settlement as a means of case resolution. See Edson R. Sunderland, Scope and Method of Discovery Before Trial, 42 YALE L.J. 863, 864 (1933) ("[O]ne of the greatest uses of judicial procedure is to bring parties to a point where they will seriously discuss settlement."). Given the relative simplicity of cases in 1938, however, trials were much more likely to occur and were much shorter than modern trials - the length of which ballooned after the 1960s. See Tidmarsh, supra note 1, at 567-68; see also Marc Galanter, The Vanishing Trial: An Examination of Trials and Related Matters in Federal and State Courts, 1 J. EMPIRICAL LEGAL STUD. 459, 477 (2004). 
civil cases today are virtually never resolved through trial. ${ }^{3}$ Rather, settlement has emerged as the dominant endgame.

The modern system of litigation today faces the same fundamental problem that vexed the 1938 reformers. As was true then, there is reason to worry that case outcomes-now the product of settlements-correspond to the legal merits of a given dispute ${ }^{4}$ in only the coarsest of ways. ${ }^{5}$ Ironically, the disorder afflicting the current system represents a new strain that draws much of its strength from the very set of rules designed in 1938 to cure it.

Because the drafters of the Federal Rules placed the mechanisms for robust merits adjudication at the end of the litigation process, ${ }^{6}$ those mechanisms are largely unavailable to influence settlement outcomes in a world without trials. As a result, the task of ensuring that settlement outcomes reflect the merits has fallen to procedural rules governing the pretrial phases of litigation. However, this is a task for which those rules were not principally designed, and there is reason to believe that it is a task for which they are not particularly well-suited.

Indeed, pretrial procedural rules tend not to mitigate, and sometimes amplify, the impact of factors unrelated to case merits on settlement outcomes. Moreover, by design, current pretrial rules are generally insufficient to inform robustly the parties' understanding of

3 See infra Part I.

4 By "the legal merits of a given dispute," I refer to the application of underlying substantive law to the relevant facts of a case. I do not, however, equate "the merits" of a dispute with a plenary, unlimited opportunity on the part of litigants to develop their claims through the potentially maximal use of procedural tools - a conception of "the merits" that may more fully encapsulate the scholar Roscoe Pound's view of a decision "on the merits." See Roscoe Pound, Some Principles of Procedural Reform, 4 ILL. L. REv. 388, 401 (1909-1910) ("With respect to ... rules of procedure, we should make nothing depend upon them beyond securing to each party his substantive rights-a fair chance to meet his adversary's case and a full opportunity to present his own."); see also Jay Tidmarsh, Resolving Cases "On the Merits," 87 DENV. U. L. REv. 407, 413 (2010) ("It is the guarantee of a full opportunityunfettered by concerns for expense, delay, or advancing certain political interests-that defines the 'on the merits' principle."). Further, there is of course an inherent uncertainty in litigation. Merits-based guidance would lead not to a single, objective result; instead, such guidance could align a range of potential outcomes more closely with the dictates of governing law.

5 See generally Owen M. Fiss, Comment, Against Settlement, 93 YALE L.J. 1073, 1088 (1984) ("The problems of settlement are not tied to the subject matter of the suit, but instead stem from factors that are harder to identify, such as the wealth of the parties, the likely post-judgment history of the suit, or the need for an authoritative interpretation of law.").

6 See, e.g., Robert G. Bone, Twombly, Pleading Rules, and the Regulation of Court Access, 94 IowA L. REV. 873, 891-92 (2009) [hereinafter Bone, Regulation of Court Access] ["Charles Clark ... chief architect of the 1938 Federal Rules ... believed that merits screening should take place after discovery, at summary judgment in some cases and at trial in most."). 
the merits of a given dispute. As a consequence, the "shadow of the law"7 $^{\prime \prime}$ cast upon settlement outcomes is growing faint. To make matters worse, distorted settlement outcomes increasingly influence other settlements, thus propagating the original distortions. ${ }^{8}$ The world of modern litigation is therefore transforming into one in which bargaining takes place in the shadow of earlier bargains.

This Article is the first to examine systematically the maladaptiveness of the Federal Rules to a world of settlement and to call for fundamental reform in light of that maladaptiveness. Part I provides a brief historical account of the Federal Rules and traces the progression from a world in which cases were frequently resolved by trial to a world now dominated by settlement. This Part also notes the transformation of the judicial role over the past few decades from one of adjudication to one of case management and settlement facilitation.

Part II explores how pretrial procedural mechanisms, designed largely as "way-stations" on the road to trial, fail to promote and at times hinder meaningful merits-based settlement terms. Moreover, distorted settlements become magnified by the feedback effects settlements have on future settlement outcomes, foreshadowing a world in which settlements occur less in the shadow of substantive law and more in the shadow of other distorted settlements.

Part III traces the source of many of these problems to three foundational assumptions underlying the Federal Rules-assumptions that the world of settlement has undermined. Those assumptions are (1) that a regime of plenary discovery facilitates the alignment of case outcomes with the merits; (2) that the proper role of pretrial adjudicative mechanisms is limited to screening out meritless cases; and (3) that procedural rules should apply the same way to all kinds of

7 The "shadow of the law" phraseology was first introduced by Robert H. Mnookin and Lewis Kornhauser. See Robert H. Mnookin \& Lewis Kornhauser, Bargaining in the Shadow of the Law: The Case of Divorce, 88 YALE L.J. 950, 968 (1979). Mnookin and Kornhauser use that metaphor to describe a confluence of factors that affect settlement outcomes, including the entitlements created by governing law, parties' preferences, transaction costs, parties' attitudes toward risk, and strategic behavior. When I refer to the "shadow of the law," I focus on the extent to which legal entitlements created by governing law (and the application of law to underlying facts) impact negotiated outcomes. See generally Stephanos Bibas, Plea Bargaining Outside the Shadow of Trial, 117 HARV. L. REv. 2463, 2464 (2004) ("The conventional wisdom is that litigants bargain toward settlement in the shadow of expected trial outcomes."); Ben Depoorter, Essay, Law in the Shadow of Bargaining: The Feedback Effect of Civil Settlements, 95 CORNELL L. REV. 957, 975 (2010) (“[P]rior settlements are a benchmark or reference point from which to consider the merits of future, similar cases.").

8 See Depoorter, supra note 7, at 976 ("[Sixty-five] percent of [surveyed] lawyers agreed that '[i]t is helpful to refer to settlements in similar cases that are favorable to your case when in front of a judge in settlement conferences."'). 
cases (uniformity) and to all types of substantive claims (transsubstantivity). Rethinking these assumptions provides the necessary foundation for redesigning a system that better aligns settlement outcomes with the substantive law under which litigation arises. ${ }^{9}$ In setting forth this framework, Part III also reviews a number of distinct reforms and reform proposals and explains how, in fact, they fit together as parts of a broad and unified reaction to the problems with the Federal Rules identified in Parts II and III. Moreover, once viewed through the lens of this Article, it becomes clear that these proposals ought to be further refined and expanded and that new examples of the sorts of reforms that would break free from these outmoded tenets are needed. This framework is offered for use by scholars, the Rules Advisory Committee, organizations like the Federal Judicial Center, and-when appropriate-Congress as a basis for redesigning the Federal Rules for a world of settlement.

What emerges from the challenges to these foundational assumptions, as well as this Article's suggestions of the types of reforms that would break free from them, is a new vision for a procedural system designed for a world of settlement-in particular, one that would convert what is now a largely detached relationship between pretrial procedure and the substantive merits of a given case into one of interdependence. Accordingly, procedural mechanisms should be harnessed to provide meaningful merits-based information to guide parties' settlement decisions, and judicial evaluation of the merits through these mechanisms should have operational consequences for determining parties' access to additional procedures, especially those that have a tendency to create settlement distortions. In short, this Article begins to lay the foundation for the redesign of current procedural rules for a world of settlement.

I

Litigation Under the Federal Rules of Civil PROCEDURE: The DisapPEARANCE OF TRIALS AND THE RISE OF SETTLEMENT

The Federal Rules of Civil Procedure, adopted in 1938, represented a significant departure from both common law and code systems of procedure and embraced instead the more discretionary

9 To be clear, this Article works within the existing realities of litigation; although the challenges to the Federal Rules are fundamental, they reflect the world in which we live rather than the world we might ideally want. Thus, I do not suggest that we jettison trials altogether, that parties who wish to go to trial be prevented from doing so, or that the existing Federal Rules fail to align outcomes with the merits in the rare cases that go to trial-questions I defer to future work. 
and individualized principles that had been used in courts of equity. ${ }^{10}$ The 1938 reformers sought primarily to eliminate procedural technicalities that prevented cases from being resolved on their merits through the application of substantive law to the facts ${ }^{11}$ and that stood as an obstacle to justice for ordinary citizens. ${ }^{12}$ To achieve this goal, the Federal Rules embraced a relatively simple model of adjudication: Cases were to be resolved on their merits at trial (by jury where appropriate ${ }^{13}$ following plenary discovery, ${ }^{14}$ and following pretrial

10 See Stephen N. Subrin, How Equity Conquered Common Law: The Federal Rules of Civil Procedure in Historical Perspective, 135 U. PA. L. REV. 909 (1987); see also, e.g., FED. R. CIV. P. 1, 11, 12(e), 13, 14, 15, 19(b), 20, 23, 26(b)(1), (c), (d), 35(a), 37(a)(4), (b)(2), 39(b), 41(a)(2), (b), 49, 50(a), (b), 53(b), 54(b), (c), 55(c), 56(c), 59(a)(1), 50(b)(1), 60(b)(6), 61, 62(b), 65(c) (following the tradition of equity courts in providing, either explicitly or implicitly, for judicial discretion, compare R. PRAC. CT. EQUITY 29 (1912) (repealed 1938), available http://ia600505.us.archive.org/10/items/rulesofpracticef00unit/rulesofpracticef00unit.pd f); FED. R. CIV. P. 2 (providing for a single form of action and abolishing multiple forms and procedural distinctions); FED. R. CIV. P. 8 (drawing upon Equity Rule 30 to set forth general rules of pleading, claims for relief, affirmative defenses, and a requirement that pleadings be concise and direct, compare R. PRAC. CT. EQUITY 25, 30 (1912) (repealed 1938), available at http://ia600505.us.archive.org/10/items/rulesofpracticef00unit/rulesofpracticef00unit.pd f); FED. R. CIV. P. 18 (drawing upon Equity Rule 26 to provide for joinder of claims and remedies, compare R. PRAC. CT. EQUITY 26 (1912) (repealed 1938), available at http://ia600505.us.archive.org/10/items/rulesofpracticef00unit/rulesofpracticef00unit.pd f); FED. R. CIV. P. 19-22 (drawing upon the joinder provisions found in Equity Rules to provide for broad joinder of parties, compare R. PRAC. CT. EQUITY 29, 37 (1912) (repealed 1938), available http://ia600505.us.archive.org/10/items/rulesofpracticef00unit/rulesofpracticef00unit.pd f); FED. R. CIV. P. 26-27 (significantly broadening discovery proceedings found under Equity, compare R. PRAC. CT. EQUITY 58 (1912) (repealed 1938), available at http://ia600505.us.archive.org/10/items/rulesofpracticef00unit/rulesofpracticef00unit.pd f).

11 See, e.g., Charles E. Clark, Procedural Fundamentals, 1 ConN. B.J. 67, 68 (1927) ("A procedural penalty can be supported only if it is a material aid in the better administration of justice."); Charles E. Clark, History, Systems and Functions of Pleading, 11 VA. L. REv. 517, 542 (1925) ("Pleading should perform the office of only aiding in the enforcement of substantive legal relations."); Charles E. Clark, The Code Cause of Action, 33 YALE L.J. 817, 817 (1924) (describing state code reform efforts to reduce interference of technicalities with "equitable principles"); James William Moore, The New Federal Rules of Civil Procedure, 6 I.C.C. PRAC. J. 41, 42 (1938) ("The Federal rules ... epitomize the new objective of all procedure ... that litigation ought to be settled on the merits and not upon some procedural ground."); see also Subrin, supra note 10, at 986 ("Proponents of... the Federal Rules wanted procedure to step aside so that cases could more easily be decided on the merits.").

12 See Roscoe Pound, The Causes of Popular Dissatisfaction with the Administration of Justice, 14 AM. LAW. 445, 447-48 (1906) (noting that procedural technicalities were creating such contentiousness in civil litigation that ordinary people intensely desired to avoid court).

13 Arthur R. Miller, Are the Federal Courthouse Doors Closing? What's Happened to the Federal Rules of Civil Procedure?, 43 TEx. TECH L. REV. 587, 588 (2011) [hereinafter Miller, Are the Federal Courthouse Doors Closing?].

14 See Wayne D. Brazil, The Adversary Character of Civil Discovery: A Critique and 
processes that were designed to facilitate accurate trial outcomes. To be sure, settlement was not foreign to the 1938 reformers. ${ }^{15}$ And disposition of cases was possible through summary judgment, but summary judgment was meant to be rare, and it was infrequently granted in the years immediately following the adoption of the new Federal Rules. ${ }^{16}$ Dispositive adjudication, to the extent it occurred, was to come at trial or through directed verdict. ${ }^{17}$ This model of case resolution dominated in 1938 and prevailed for many years thereafter. ${ }^{18}$

While the Federal Rules have remained fundamentally unchanged since 1938, ${ }^{19}$ the litigation landscape in which those Rules operate has changed significantly. As is now well known, federal civil trials-the fulcrum around which the Federal Rules were structured ${ }^{20}$-are now a rarity. ${ }^{21}$

Proposals for Change, 31 VAND. L. REv. 1295, 1301 (1978) (noting that the 1938 drafters aimed to increase disclosure to reduce the adversarial nature of trial preparation); Charles E. Clark, Pleading Under the Federal Rules, 12 WYo. L.J. 177, 188-90 (1958) (noting that the 1938 reformers sought to place "truth ahead of cleverness and tactics" and to enable citizens "to come in and put [their] claim before the judge").

15 See, e.g., Sunderland, supra note 2, at 864 ("[0]ne of the greatest uses of judicial procedure is to bring parties to a point where they will seriously discuss settlement."); Tidmarsh, supra note 4, at 414 (citing the predilections toward settlement held by Edson R. Sunderland, one of the 1938 rule drafters).

16 See Robert J. Gregory, One Too Many Rivers To Cross: Rule 50 Practice in the Modern Era of Summary Judgment, 23 FLA. ST. U. L. REV. 689, 689 (1996) ("Historically, summary judgment was a rarely used procedural device [and] [t] he standard formulation was that summary judgment should be denied whenever there was the 'slightest doubt as to the facts.'” (quoting Armco Steel Corp. v. Realty Inv. Co., 273 F.2d 483, 484 (8th Cir. 1960))).

17 Stephen C. Yeazell, Essay, The Misunderstood Consequences of Modern Civil Process, 1994 WIS. L. REV. 631, 636. In 1938, roughly sixty-three percent of adjudicated terminations of cases terminated in trials and directed verdicts. Id. (citing 1938 ATT'Y GEN. ANN. REP. 1, 233).

18 Miller, Are the Federal Courthouse Doors Closing?, supra note 13, at 588.

19 There have been few major substantive amendments to the Federal Rules since their adoption in 1938. See, e.g., FED. R. CIV. P. 11 (amended in 1983 to require lawyers to certify that their filings are supported by fact and law after an "inquiry reasonable under the circumstances"); FED. R. CIV. P. 16 (amended in 1983 to encourage judges to exercise a managerial role during pretrial settlement conferences); FED. R. CIV. P. 16, 26, 33, 34, 37, 45 (amended in 2006 to clarify that discoverable materials also cover electronic data); FED. R. Civ. P. 26 (amended in 1970 to exclude attorney work product from discoverable documents, in 1993 to require disclosure of certain documents at the outset of discovery, and in 2000 to require parties to disclose those documents only if they intended to use them "to support [their] claims or defenses").

20 See Miller, Are the Federal Courthouse Doors Closing?, supra note 13, at 588 (citing AM. Bar Ass'N, PRoceEdings of the Institute on Federal Rules, Cleveland, OHio 240 (William W. Dawson ed., 1938) and Clark, supra note 14, at 177-80); see also Clark, supra note 14, at 193-95 (describing the Federal Rules of Civil Procedure as an adaptation of old civil procedure rules to the needs of modern courts).

21 See, e.g., Charles A. Brown, Note, Employment Discrimination Plaintiffs in the District of Maryland, 96 CORNELL L. REv. 1247, 1252 n.37 (2011) (noting a trial rate of around 1.2\% for 
This change "is not a mere difference of degree." 22 Various factors have contributed to the decline of trials. The increase in the number of criminal cases and private causes of action ${ }^{23}$ has caused crowded dockets that create strong incentives for judges to encourage the resolution of cases before trial. ${ }^{24}$ At the same time, cases have grown in complexity and scope, ${ }^{25}$ especially in light of modern class action practice, ${ }^{26}$ often making trial impracticable. In fact, as federal cases

civil court filings); Kevin M. Clermont, Litigation Realities Redux, 84 NotRe DAmE L. Rev. 1919, 1956 n.184 (2009) ("[T]he Annual Report of the Director of the Administrative Office of the United States Courts ... shows ... current [trial] levels approaching 1\%.”).

22 Richard A. Nagareda, 1938 All Over Again? Pretrial as Trial in Complex Litigation, 60 DePaul L. Rev. 647, 647 (2011) (citing Marc Galanter, The Vanishing Trial: An Examination of Trials and Related Matters in Federal and State Courts, 1 J. EMPIRICAL LEGAL STUD. 459, 460 (2004) ("[J]udges conduct trials at only a fraction of the rate that their predecessors did .... [This is] a phenomenon that runs counter to the prevailing image of litigation in the United States.")).

23 See, e.g., David L. Cook et al., Criminal Caseload in U.S. District Courts: More than Meets the Eye, 44 AM. U. L. REV. 1578, 1580 (1995) ("Federal judges today are spending a disproportionate amount of their time on criminal cases, due to the increase in defendants, trials, motions, hearings, and sentencings."); see also generally J. Maria Glover, The Structural Role of Private Enforcement Mechanisms in Public Law, 53 WM. \& MARY L. ReV. 1137, 1148 (2012) (describing Congress's increasing departure in the last five decades from reliance upon bureaucratic enforcement in favor of reliance upon ex post private litigation as a basis of American regulatory enforcement).

24 See Samuel R. Gross \& Kent D. Syverud, Don't Try: Civil Jury Verdicts in a System Geared to Settlement, 44 UCLA L. REv. 1, 3, 59 (1996) [hereinafter Gross \& Syverud, Don't Try] (noting that "[w]e have very many litigated disputes per judge, so it is essential that most cases be resolved without judgment"). But see Shari S. Diamond \& Jessica Bina, Puzzles About Supply-Side Explanations for Vanishing Trials: A New Look at Fundamentals, $1 \mathrm{~J}$. EMPIRICAL LEGAL STUD. 637, 638 (citing Galanter, supra note 22, at 500) (rejecting the notion that a scarcity of judicial resources explains the vanished trial). The federal judiciary continues to claim that the growing workload impairs its ability to handle its cases. E.g. id. Despite suggestions that the addition of more judges would usher in a world of increased trials, see, for example, John Lande, How Much Justice Can We Afford?: Defining the Courts' Roles and Deciding the Appropriate Number of Trials, Settlement Signals, and Other Elements Needed To Administer Justice, 2006 J. DISP. RESOL. 213, 248, it may well be that any room for trials made by the addition of judges would simply be occupied by other cases waiting in the wings. See George L. Priest, Private Litigants and the Court Congestion Problem, 69 B.U. L. REV. 527, 554 (1989) (introducing the congestion equilibrium hypothesis).

25 See, e.g., Access to Justice Denied: Ashcroft v. Iqbal: Hearing Before the Subcomm. on the Constitution, Civil Rights \& Civil Liberties of the H. Comm. on the Judiciary, 111th Cong. 11 (2009) (statement of Arthur R. Miller, Professor, New York University School of Law) ("The federal courts have become a world unimagined in 1938: a battleground for titans of industry to dispute complex claims involving enormous stakes... and the situs for aggregate litigation on behalf of large numbers of people and entities pursuing legal theories and invoking statutes unknown in the 1930s.").

26 See, e.g., Martha Minow, Judge for the Situation: Judge Jack Weinstein, Creator of Temporary Administrative Agencies, 97 CoLUM. L. REv. 2010, 2019-20 (1997) (discussing Judge Weinstein's handling of In re "Agent Orange" Product Liability Litigation, 611 F. Supp. 1396 (E.D.N.Y. 1985), a complex mass tort case, in which he "pressed for settlement" while also creating an administrative-like regime to process individual claims); Richard A. Nagareda, Turning from Tort to Administration, 94 MICH. L. REV. 899, 902 (1996) (pointing 
have become more complex, ${ }^{27}$ the cost of litigating a case to trial has become prohibitive, or at least undesirable, for many litigants. Further, litigants-particularly repeat player defendants ${ }^{28}$ - have consciously adopted a strategy of avoiding trials to steer clear of juries and to increase predictability of outcomes. ${ }^{29}$ And many litigants view settlement as permitting more creative resolutions than the zero-sum game of trial. ${ }^{30}$ Finally, the federal civil trial's decline was probably aided by Supreme Court rulings that provide for more robust judicial intervention at various procedural steps prior to trial, including summary judgment, ${ }^{31}$ class certification, ${ }^{32}$ the admissibility of expert

out that the rise of mass tort settlements occurred "outside preexisting channels of control").

27 Scholars have noted that the prototypical lawsuit for which the 1938 Federal Rules were designed was a relatively simple diversity case, not the often staggeringly complex cases brought in federal court today. See, e.g., Judith Resnik, Failing Faith: Adjudicatory Procedure in Decline, 53 U. CHI. L. REv. 494, 508 (1986) (noting that the prototypical case in the minds of the 1938 drafters was one between private individuals in which "tortious injury or breach of contract was claimed ... and monetary damages were sought").

28 Marc Galanter, Why the "Haves" Come out Ahead: Speculations on the Limits of Legal Change, 9 L. \& Soc. REv. 95, 97 (1974) (describing repeat players as actors "who are engaged in many similar litigations over time").

29 See Shari Diamond, Truth, Justice, and the Jury, 26 HARV. J. L. \& PuB. PoL'y 143, 144 (2003) ("The general theme [among civil jury critics] is that a group of laypersons cannot be trusted to find the truth and to administer even-handed justice."); Marc Galanter, Real World Torts: An Antidote to Anecdote, 55 MD. L. REv. 1093, 1095 (1996) (noting that critics of the tort system believe that "[i]rresponsible juries, biased against deep-pocket defendants, bestow windfalls on undeserving plaintiffs, particularly arbitrary and capricious damages for pain and suffering and random outsize awards of punitive damages"); Marc Galanter, The Civil Jury as Regulator of the Litigation Process, 1990 U. CHI. LEGAL F. 201, 208 (1990) ("Fear of juries leads defendants to settle suits, whatever their merits."); Wendy Parker, Lessons in Losing: Race Discrimination in Employment, 81 Notre DAME L. REV. 889, 921 (2006) ("Defendants fear a trial, with its unpredictable outcome ....").

30 See, e.g., Carrie Menkel-Meadow, Whose Dispute Is It Anyway? A Philosophical and Democratic Defense of Settlement (In Some Cases), 83 GE0. L.J. 2663, 2674-75 (1995) (noting that settlement enables litigants to craft solutions that offer "greater expression of the variety of remedial possibilities in a postmodern world").

31 In 1986, three decisions of the Supreme Court cemented a shift in the focal point of litigation to the summary judgment stage. See Anderson v. Liberty Lobby, Inc., 477 U.S. 242, 256-57 (1986) (requiring the nonmovant, under the standard governing a directed verdict, to provide affirmative evidence supporting a favorable verdict); Celotex Corp. v. Catrett, 477 U.S. 317, 323 (1986) (easing the movant's burden by allowing her to prevail without proving the nonexistence of material facts); Matsushita Elec. Indus. Co. v. Zenith Radio Corp., 475 U.S. 574, 587 (1986) (requiring the nonmovant, in the face of a judicial determination that her claims are "implausible," to produce affirmative evidence to the contrary). Together, these three cases formalized the transformation of summary judgment from a relatively unused-and even disfavored-procedure into a powerful resolver of disputes. See, e.g., Samuel Issacharoff \& George Loewenstein, Second Thoughts About Summary Judgment, 100 YALE L.J. 73, 87-89, 95 (1990); Joe S. Cecil et al., A Quarter-Century of Summary Judgment Practice in Six Federal District Courts, 4 J. EMPIRICAL LEGAL STUD. 861, 906 (2007) (demonstrating that the Supreme Court's invigoration of the summary judgment procedure confirmed, rather than started, the trend toward higher levels of 
evidence, ${ }^{33}$ and the pleading stage. ${ }^{34}$ These changes have helped to ensure that the pretrial stage is now the focal point of litigation.

While trials have all but disappeared, settlement, though not a completely new development in the world of litigation, has become the dominant mode of civil dispute resolution. Today, most cases terminate in settlement. ${ }^{35}$ The number is even higher for class actions. ${ }^{36}$

The rise of settlement was reinforced by a shift in judicial attitudes and approaches toward litigation. In particular, in the 1970s, judges began to adopt a more managerial role over their cases in an attempt to deal with growing dockets and to control costs. ${ }^{37}$ This

judicial intervention at the summary judgment stage).

32 See Wal-Mart Stores, Inc. v. Dukes, 131 S.Ct. 2541, 2551 (2011) (holding that in order to certify a class, a court must find that the class has presented a common contention of injury, the validity of which can be resolved in one stroke). A series of recent appellate court decisions have called for more robust judicial scrutiny of merits-related issues at the class certification stage. See In re Hydrogen Peroxide Antitrust Litig., 552 F.3d 305, 320, 324 (3d Cir. 2008) (requiring judges to determine whether the requirements for class certification under Federal Rule 23 are satisfied by a preponderance of the evidence); In re Pub. Offering Sec. Litig., 471 F.3d 24, 37 (2d Cir. 2006) (same).

33 See Daubert v. Merrell Dow Pharm., Inc., 509 U.S. 579, 589-91 (1993) (stating that expert testimony is only admissible if a judge deems it relevant, reliable, and grounded in sound scientific methodology).

34 The Court recently ushered in demands for more robust judicial intervention at the pleading stage of litigation. In two cases, Bell Atlantic Corp. v. Twombly, 550 U.S. 544, 561, 570 (2007), and Ashcroft v. Iqbal, 556 U.S. 662, 678 (2009), the Court abandoned the longstanding "no set of facts" pleading standard from Conley v. Gibson, 335 U.S. 41, 45-46 (1957) and replaced it with one that requires a complaint to "state a claim to relief that is plausible on its face."

35 See, e.g., Clermont, supra note 21, at 1953 (noting that "the settlement rate is high"); Marc Galanter \& Mia Cahill, "Most Cases Settle": Judicial Promotion and Regulation of Settlements, 46 STAN. L. REV. 1339, 1340 (1994) (referring to research indicating that, even twenty-five years ago, seventy-eight percent of surveyed cases ended in settlement) (citing Herbert M. Kritzer, Adjudication to Settlement: Shading in the Gray, 70 JUDICATURE 161, 16264 (1986)); Tidmarsh, supra note 1, at 555 (noting that eighty percent of cases end in "settlement, arbitration, or voluntary dismissal").

36 FED. JUdicial CTR., IMPACT OF THE Class ACtion FAIRNESS ACT ON THE FEdERAL Courts: Preliminary Findings from Phase Two's Pre-CAFA SAmple of Diversity Class ACtions 2 (2008), available

http://www.fjc.gov/public/pdf.nsf/lookup/cafa1108.pdf/\$file/cafa1108.pdf (finding that, among diversity cases, every certified class action in its post-Class Action Fairness Act (CAFA) study had terminated in settlement); see also 28 U.S.C. $\S \S 1332(d)(2), 1453$ (expanding federal courts' jurisdiction under the diversity statute over class actions to those in which the total amount in controversy exceeds $\$ 5$ million). Rarely, but not never, do such settlements follow a trial. See In re Vitamins Antitrust Litig., No. 99-197, 2003 WL 22089938 , at $* 1$ (D.D.C. Sept. 4, 2003) (noting that plaintiffs' allegations regarding a global cartel price-fixing vitamins resulted in a $\$ 49.5$ million jury verdict before trebling, then the parties settled the matter after trial but before judgment was entered).

37 See, e.g., Judith Resnik, Managerial Judges, 96 HARV. L. REV. 374, 376-77 (1982) ("In growing numbers, judges ... are meeting with parties in chambers to encourage settlement 
managerial role rapidly evolved from one aimed at the "the business of adjudication" to one aimed at "the business of settlement." 38 Indeed, available empirical evidence reveals not only that managerial judging facilitates early case disposition, ${ }^{39}$ but also that it is frequently conducted with that explicit goal in mind. ${ }^{40}$

Scholars have vigorously debated whether the rise of settlement is desirable. Critics charge that settlement deprives the judicial system of public pronouncements of the law ${ }^{41}$ and provides a vehicle through which defendants, often with the aid of confidentiality agreements and sealed court records, can conceal harmful practices from the public eye. $^{42}$ They also assert that managerial judging fails to increase efficiency, and instead produces subjective or even arbitrary outcomes

of disputes and to supervise case preparation.").

38 Resnik, supra note 27, at 528.

39 See Edward J. Brunet, Martin H. Redish \& Michael A. Reiter, Summary Judgment: FEDERAL LAW AND PRACTICE 38-39 (2d ed. 2000) ("Summary judgment thereby enhances settlement possibilities by eliminating sometimes troublesome and illusory issues from a case."); Peter Robinson, Settlement Conference Judge_Legal Lion or Problem Solving Lamb? An Empirical Documentation of Judicial Settlement Conference Practices and Techniques, 33 AM. J. TRIAL ADV. 113, 132 (2009) (reporting that a majority of California judges surveyed believed that they were "influential" on parties' decisions to settle "between $41 \%$ and $60 \%$ of the time").

40 The idea of the judge as "settlement facilitator" was more formally cemented by legislative enactments. See Civil Justice Reform Act of 1990, 28 U.S.C. §§ 471, 482 (2006) (emphasizing the importance of early judicial intervention to manage cases and requiring every federal district court to promulgate an expense and delay reduction plan and to conduct annual docket assessments); Private Securities Litigation Reform Act of 1995 (PSLRA), Pub. L. 104-67, 109 Stat. 743, 758 (codified as amended at 15 U.S.C. $§ 78 \mathrm{u}-4$ (2006)) (encouraging judges to weed out "frivolous" securities cases early in the litigation). This role was further embedded as a result of the 1983 amendment to the Federal Rules of Civil Procedure providing that "[a] settlement conference is appropriate at any time" during the litigation, and that "settlement should be facilitated at as early a stage of the litigation as possible," as settlement "obviously eases crowded court dockets and results in savings to the litigants and the judicial system." FED. R. Civ. P. 16 advisory committee's note. See also Robinson, supra note 39, at 143, 146 (reporting that seventy-five percent of judges surveyed are motivated to settle cases because settlement engenders a sense of accomplishment, and that ninety percent of judges believe settlement is in the litigants' best interests in upwards of sixty percent of their settlement conferences).

41 Fiss, supra note 5, at 1089. More broadly, scholars have also argued that settlement deprives the litigation system of needed clarification of legal norms, David Luban, Settlements and the Erosion of the Public Realm, 83 GEo. L.J. 2619, 2622-23 (1995), that it prevents the public from learning about legal processes and outcomes, and that it prevents our regulatory system from using litigation to place topics on the public agenda independent of those that governmental institutions might place there, Judith Resnik, Courts: In and out of Sight, Site, and Cite, 53 VILL. L. REV. 771, 804-06 (2008).

42 See Blanca Fromm, Bringing Settlement out of the Shadows: Information About Settlement in an Age of Confidentiality, 48 UCLA L. REv. 663, 663 (2001) (noting that the details of settlements are usually hidden from the public via sealed court orders and confidentiality agreements); Luban, supra note 41, at 2649 (same). 
because of its discretionary and non-transparent nature. ${ }^{43}$ Defenders argue that settlements achieve cost savings to litigants and to the judicial system, ${ }^{44}$ enable more flexible remedies, ${ }^{45}$ bring about greater party satisfaction, ${ }^{46}$ eliminate some of the uncertainties and delays of trial, ${ }^{47}$ and, in many instances, mean the difference between a deal for injured plaintiffs and no compensation whatsoever, particularly in cases of mass harm. ${ }^{48}$ Normative disagreements aside, however, scholars agree on one thing: Settlement is here to stay. ${ }^{49}$

\section{II}

\section{The Vanishing Shadow of the LaW And the Growing Shadow of SetTlement}

The aspiration behind the 1938 Rules-that cases be resolved on their merits, and in a "speedy, just, and inexpensive"50 mannerremains laudable. But the affliction that the 1938 reformers sought to

43 See, e.g., E. Donald Elliot, Managerial Judging and the Evolution of Procedure, 53 U. CHI. L. REV. 306, 316-18 (1986) (describing how the unavailability of certain legal safeguards in settlement conferences encourages arbitrary decisions by judges); Jonathan T. Molot, An Old Judicial Role for a New Litigation Era, 113 YALE L.J. 27, 42 (2003) [hereinafter Molot, An Old Judicial Role] ("[D]iscretionary management tactics that vary inordinately from judge to judge may threaten litigants' due process rights ...."); Jeffrey A. Parness, Improving Judicial Settlement Conferences, 39 U.C. DAVIS L. REV. 1891, 1893-98 (2006) (comparing a judge's limited "traditional judicial role" with the discretionary, informal, and overreaching powers exercised in a settlement conference); Resnik, supra note 37, at 425-26 (describing a judge whose decisions in settlement were "made privately, informally, off the record, and beyond the reach of appellate review").

44 See Galanter \& Cahill, supra note 35, at 1360 ("It seems probable that settlement generally does involve the expenditure of fewer resources than adjudication."). However, Galanter and Cahill note that settlement may reduce costs asymmetrically; in other words, some classes of litigants-primarily insurers-may capture a greater share of these cost savings than others. Id. at 1363-64.

45 See Gross \& Syverud, Don't Try, supra note 24, at 7 ("Compromise ... is the essence of settlement....").

46 See Menkel-Meadow, supra note 30, at 2693 (noting that settlement can be "empowering," "participatory," and "transformative" for litigants).

47 See, e.g., Samuel Issacharoff \& Robert H. Klonoff, The Public Value of Settlement, 78 FoRDHAM L. REV. 1177, 1196-99 (2009) (explaining how settlement in some cases is vastly preferred to the potential delays and uncertainties litigation can introduce).

48 See id. at 1197-98 (noting that, absent settlement, plaintiffs who had been injured by Vioxx would have risked a defense verdict, "even those with stronger claims").

49 Suzanna M. Meyers, Doing Their Jobs: An Argument for Greater Media Access to Settlement Agreements, 14 FordhAM InTELL. Prop. MEdia \& ENT. L.J. 603, 606 (2004); see also, e.g., Nancy Levit, Megacases, Diversity, and the Elusive Goal of Workplace Reform, 49 B.C. L. REV. 367, 376 (2008) ("Most [lawsuits], and particularly complex cases, settle anyway, and this trend toward settlement is likely to increase."); Nancy S. Marder, Introduction to Secrecy in Litigation, 81 CHI.-KENT L. REV. 305, 329 (2006) (noting that a pilot project creating a settlement database for magistrate judges in Chicago started with the assumption that "settlement agreements are here to stay"); Menkel-Meadow, supra note 30, at 2664-65 (referring to settlement as "the 'norm' for our system").

50 FED. R. CIV. P. 1. 
remedy-case outcomes that do not meaningfully correspond to the merits of the underlying claims ${ }^{51}$-has re-emerged in a new strain. Current pretrial procedures insufficiently address, and at times amplify, the effect on settlement outcomes of factors like cost imposition, informational asymmetries, and variance (uncertainty of settlement range outcomes). These external factors can have a significant impact on settlement values. ${ }^{52}$ In addition, I argue, these pretrial procedures, as a matter of design, fail to meaningfully inform parties' understanding of the merits of the dispute. ${ }^{53}$ Thus, the shadow

51 See Roscoe Pound, Some Principles of Procedural Reform (pt. 1), 4 ILL. L. REV. 388, 402 (1910) ("[R]ules of procedure should exist only to secure to all parties a fair opportunity to meet the case against them and a full opportunity to present their own case; and nothing should depend on or be obtainable through them except the securing of such opportunity."); see also Tidmarsh, supra note 1, at 533 (noting that one appealing feature of Pound's view is the principle of resolving cases "on the merits"). This goal is sometimes referred to as one of "accuracy." See, e.g., Jonathan T. Molot, Litigation Finance: A Market Solution to a Procedural Problem, 99 GE0. L.J. 65, 65 (2010) (describing "accuracy in litigation" as producing outcomes that reflect the merits of a dispute). It is important to note, however, that believing in a single correct answer to factual and legal questions is overly simplistic. Tidmarsh, supra note 4, at 409 ("[A] single correct answer to either factual or legal questions, or in the application of the latter to the former, is elusive."); $c f$. Lawrence B. Solum, Procedural Justice, 78 S. CAL. L. REV. 181, 247-50 (2004) (categorizing accuracy from either ex ante or ex post perspective and describing tradeoffs between these two perspectives). Accordingly, when I say that settlement outcomes infrequently reflect "the merits" of an underlying dispute, I do not suggest that there is one perfect outcome for every case; rather, I argue that merits-based guidance could better narrow a range of possible outcomes in line with the dictates of governing substantive law as applied to fact.

52 These external factors may have a less significant impact on settlements in less complex cases that involve no discovery. See Judith A. McKenna \& Elizabeth C. Wiggins, Empirical Research on Civil Discovery, 39 B.C. L. REv. 785, 790-92 (1998) (reporting, based on a study from 1978, that around fifty-two percent of cases in federal court involve no discovery, and that discovery incidents track case complexity, number of parties, and amounts at stake). This is particularly true given the costs associated with the discovery process for more complex cases. See Scott A. Moss, Litigation Discovery Cannot Be Optimal but Could Be Better: The Economics of Improving Discovery Timing in a Digital Age, 58 DUKE L.J. 889, 892 (2009) (stating that in federal cases involving discovery, discovery constitutes half of all litigation costs, and in the most expensive five percent of cases, ninety percent of litigation costs).

The numbers on discovery incidents are likely too low, particularly given the recent explosion of electronic discovery. See, e.g., John H. Beisner, Discovering a Better Way: The Need for Effective Civil Litigation Reform, 60 DuKE L.J. 547, 572 (2010) (pointing out that most studies on discovery are out of date because they were conducted before the "explosion of electronic discovery" over the last decade, which hinders the resolution of even routine cases). And it is important to note that statistics about the incidence of discovery can be misleading: As Judge Frank Easterbrook has argued, the threat of discovery may be as problematic as discovery itself. Frank H. Easterbrook, Discovery as Abuse, 69 B.U. L. REv. 635, 637 (1989) ("[T] he terms of settlement are affected the most when the parties threaten discovery (explicitly or implicitly) but never use it.").

53 To be clear, this Part does not argue that the merits of a dispute do not influence settlement outcomes whatsoever, as has been asserted in the context of securities class actions. See, e.g., Janet Cooper Alexander, Do the Merits Matter? A Study of Settlements in 
that governing substantive law casts upon parties' bargains is growing faint.

Moreover, the "precedents" generated in a world of settlementnamely, prior settlement outcomes-may distort the existing settlement market even further through feedback effects. Contrary to the conventional account of settlements, characterized as unknown and unknowable, empirical evidence reveals that prior settlement outcomes, which internalize the various distortions mentioned above, now serve as an increasingly important determinant of future settlements. As the shadow of the law is fading, a new shadow is emerging: the shadow of settlement.

\section{A. The Vanishing Shadow of the Law}

Conventional wisdom holds that settlement occurs in the shadow of the law $^{54}$-more specifically, that legal entitlements created by governing substantive law have a decided impact on settlement outcomes. However, this conventional view is increasingly questionable today. As this section traces, the pretrial procedural mechanisms upon which the system of litigation now largely relies for the resolution of disputes tend not to help meaningfully align outcomes with the merits of given cases.

\section{Overshadowed Shadows: Pretrial Procedures Inadequately Address the Impact of Non-merits Factors on Settlement Outcomes}

Settlement outcomes are susceptible to the influence of a number of non-merits factors. Indeed, as law and economics, finance-based, and empirical models of modern litigation have revealed, litigation costs, informational asymmetries, and variance can crowd out the merits of a claim by influencing settlement outcomes. ${ }^{55}$ Psychological

Securities Class Actions, 43 STAN. L. REv. 497, 524 (1991) ("Because the safety valve of adjudication is not available, the strength of the case on the merits simply drops out of the settlement calculus."). Alexander's conclusions have been challenged. See, e.g., Tom Baker \& Sean J. Griffith, How the Merits Matter: Directors' \& Officers' Insurance and Securities Settlements, 157 U. PA. L. REv. 755, 757-59 (2009) (suggesting the veracity of Alexander's claims is ambiguous because several studies "may support the proposition that at least some meritorious claims settle higher than nonmeritorious claims").

54 Again, by the "shadow of the law," I refer to the view that legal entitlements created by governing law (and the application of law to underlying facts) guide negotiated outcomes. See, e.g., Bibas, supra note 7, at 2464 ("The conventional wisdom is that litigants bargain toward settlement in the shadow of expected trial outcomes."); William J. Stuntz, Plea Bargaining and Criminal Law's Disappearing Shadow, 117 HARV. L. REV. 2548, 2548 (2004) (stating that the settlement market in civil cases "internalizes the governing law").

55 See generally Steven Shavell, Foundations of ECONOMic ANALYSiS OF LAW 401-03 (2004) (setting forth the economic model of litigation); Geoffrey P. Miller, Settlement of 
models of litigation show that litigants' cognitive biases tend to exacerbate these problems. ${ }^{56}$

Existing literature on these phenomena is extensive and illuminating. However, the insights of existing litigation models have not been viewed together with a systemic focus on the ways in which the impact of these forces on settlement is inevitable given modern litigation practice under the Federal Rules. Indeed, only by viewing these issues through the lens of the mismatch between the current procedural rules and a world of settlement does it become clear that these issues are in some ways the unsurprising products of rules that were simply designed to do something else. The goal here is thus to accept the central insights about these distortions of settlement outcomes, ${ }^{57}$ expand upon them, and situate them within a larger narrative about the functioning of the Federal Rules in a world of settlement. By adopting this broader perspective, it is possible to see how these distortions have become engrained in-and indeed are perpetuated by-our system of civil procedure in a world of settlement.

\section{a. Litigation Costs}

Economic models of litigation, as well as recent empirical studies,

Litigation: A Critical Retrospective, in Reforming the Civil Justice System 13, 13-37 (Larry Kramer ed., 1996) (describing the economic model in detail). For a discussion of how the threat of costs can overwhelm the merits, see Lucian Arye Bebchuk, Suing Solely To Extract a Settlement Offer, 17 J. LEGAL STUD. 437, 445-46 (1988) [hereinafter Bebchuk, Suing Solely], and Jonathan T. Molot, How U.S. Procedure Skews Tort Law Incentives, 73 IND. L.J. 59, 69-72 (1997). For a discussion of how informational asymmetries can affect case outcomes, see Lucian Arye Bebchuk, Litigation and Settlement Under Imperfect Information, 15 RAND J. ECON. 404, 409, 413-14 (1984). And for a presentation of a finance-based model of litigation that focuses on variance as a driver of settlement outcomes, see Joseph A. Grundfest \& Peter H. Huang, The Unexpected Value of Litigation: A Real Options Perspective, 58 STAN. L. REv. 1267, 1278 (2006).

56 See, e.g., Chris Guthrie, Framing Frivolous Litigation: A Psychological Theory, 67 U. CHI. L. REv. 163, 168-69 (2000) (proposing that, in frivolous lawsuits, plaintiffs are "psychologically inclined toward trial," and defendants are "psychologically inclined toward settlement"); George Loewenstein et al., Self-Serving Assessments of Fairness and Pretrial Bargaining, 22 J. LEGAL STUD. 135, 138-40 (1993) (discussing "psychological factors that challenge [the Priest-Klein model's] central assumptions"); Jeffrey J. Rachlinski, Gains, Losses, and the Psychology of Litigation, 70 S. CAL. L. REv. 113, 128 (1996) ("Predicting the behavior of litigants... requires an understanding of whether a party views their decision from the perspective of a gain or loss.").

57 By "distortions of settlement outcomes," I refer to the phenomenon whereby the operation of procedural rules in a particular case enables or amplifies the influence of nonmerits factors on settlement outcomes to such a degree that those factors may overwhelm the merits of the claim. And when I refer to "distortion of settlement ranges," I refer to a shift in those ranges, either higher or lower, to a different set of minimum and maximum values for reasons largely unrelated to the merits of the relevant case. 
strongly support the conclusion that litigation costs can significantly affect settlement outcomes. ${ }^{58}$ It is well known that defendants will sometimes pay more prior to trial and plaintiffs will sometimes settle for less than is called for by the merits of plaintiffs' claims to avoid litigation costs..$^{59}$ Of course, the Federal Rules and their application by the Supreme Court have attempted to take into account the effects of cost imposition on litigation outcomes. ${ }^{60}$ Moreover, there are obvious reasons to suppose that the optimal litigation cost is not zero. ${ }^{61}$ Nonetheless, the Federal Rules inadequately direct litigation costs toward the generation of merits-based signals, and therefore in cases litigated under the Federal Rules, litigation costs-or the threat of

58 See SHAVELL, supra note 55, at 401-03 (outlining the basic economic model of litigation); Bruce L. Hay \& Kathryn E. Spier, Settlement of Litigation, in 3 The New PALGRAVE DicTIONARY OF ECONOMICS AND THE LAW 442, 442, 445 (Peter Newman ed., 1998) (discussing the effects of litigation costs on the likelihood and terms of settlement). For empirical work reporting that eighty-three percent of responding lawyers agreed that costs, and not the merits of a case, were the deciding factor in settlement decisions, see AM. COLL. OF TRIAL LAW. TASK FORCE ON DISCOVERY \& INST. FOR THE ADVANCEMENT OF THE AM. LEGAL SYS., INTERIM REPORT on the Joint Project of the American College of Trial LaWyers Task Force on Discovery AND the Institute For the Advancement of THE AMERICAN Legal System, at A-6 (2008), available at http://druganddevicelaw.net/ACTL\%20Discovery\%20Report.pdf.

59 See, e.g., Samuel R. Gross \& Kent D. Syverud, Getting to No: A Study of Settlement Negotiations and the Selection of Cases for Trial, 90 MicH. L. REv. 319, 323-24 (1991) [hereinafter Gross \& Syverud, Getting to No] ("[The] plaintiff's minimum settlement demand [equates to] the plaintiff's estimate of the expected judgment at trial, minus the plaintiff's litigation costs. Similarly, the defendant's maximum settlement offer equals the defendant's estimate of the expected judgment at trial, plus the defendant's litigation costs." (emphases omitted) (citing George L. Priest \& Benjamin Klein, The Selection of Disputes for Litigation, 13 J. LEGAL STUD. 1, 12 (1984))); Issacharoff \& Loewenstein, supra note 31, at 98 ("[Assuming] the plaintiff's expected value of going to trial is ... $\$ 725,000$ [and] the defendant's expected loss is $\$ 850,000 \ldots$. [t] he plaintiff would prefer any settlement that provided a payment greater than $\$ 725,000$ and the defendant would prefer any settlement that provided a payment less than $\$ 850,000$."); Miller, From Conley, supra note 2, at 65 ("It is reasonable to assume that litigation cost is a factor that may encourage or induce one or more parties to settle in some cases.").

60 For instance, the Supreme Court introduced a new plausibility pleading standard partly out of concern that discovery costs may be incurred asymmetrically by defendants, thus generating undue settlement pressure. See Ashcroft v. Iqbal, 556 U.S. 662, 685 (2009) (stating that it is "quite likely" defendants must participate in discovery despite promises of deferral from plaintiffs); Bell Atl. Corp. v. Twombly, 550 U.S. 544, 559 (2007) (concluding that unnecessary discovery costs will be avoided by requiring sufficient conspiracy allegations). For an economic discussion of litigation as a vehicle to extract settlement through the imposition of costs, see Bebchuk, Suing Solely, supra note 55, at 437-38.

61 For instance, some modicum of discovery costs is needed to compel the disclosure of information that would otherwise remain in the hands of the defendant, see, for example, Robert J. Rhee, A Price Theory of Legal Bargaining: An Inquiry into the Selection of Settlement and Litigation Under Uncertainty, 56 EMORY L.J. 619, 676-77 (2006) [hereinafter Rhee, $A$ Price Theory], where the author explains how information disclosure will reduce informational uncertainty and thus lower litigation costs by encouraging earlier settlement, and is justified by the promise of vindicating a potentially meritorious claim. 
them-have the potential to overshadow the merits as a significant driver of settlement outcomes.

For starters, the transformation of pretrial procedures into significant, often terminal, litigation events has substantially increased the absolute costs attendant to those procedures. In some cases, these costs can together exceed the costs of trial. ${ }^{62}$ All other things equal, the threat of these costs-separate and apart from the merits-based information such costs might generate-can cause parties to revise settlement estimates. ${ }^{63}$ In some cases, settlement values will be shifted systematically downward (or upward) because under-resourced plaintiffs (or defendants) cannot proceed, or at least credibly threaten to proceed, deep into the litigation process. ${ }^{64}$ Similar effects can occur in cases involving a one-shot claimant whose stakes in an individual case are asymmetrically low in comparison to those of a defendant willing to expend disproportionate resources to set a low settlement value as precedent for future cases or to cement a reputation for being costly to sue. ${ }^{65}$

Pretrial procedural rules can also exacerbate the effect of litigation costs to the extent those rules impose such costs asymmetrically, either between the parties or temporally. ${ }^{66}$ As to who must incur particular costs, all things being equal, the party facing higher costs will settle on terms more favorable to the party facing lower costs. As to when such costs are incurred, ${ }^{67}$ all things being equal, a party who can defer the bulk of litigation costs until a later stage in the litigation can generally achieve a shift in the settlement range in her favor. 68

62 See, e.g., John Bronsteen, Against Summary Judgment, 75 GEO. WASH. L. REV. 522, 533 (2007) (noting that trial is often less expensive than discovery and pretrial motions).

63 See, e.g., Easterbrook, supra note 52, at 637 (stating that the threat of discovery costs affects settlement terms "most").

64 See, e.g., Elizabeth J. Cabraser, Uncovering Discovery 33 (May 10, 2010) (unpublished manuscript), available

at http://www.uscourts.gov/uscourts/RulesAndPolicies/rules/Duke\%20Materials/Library/E lizabeth\%20Cabraser,\%20Uncovering\%20Discovery.pdf (noting an assumption by courts that litigants have "infinite" resources and arguing that discovery abuse is "diminish[ing] civil litigation into a game for the rich").

65 See generally Galanter, supra note 28, at 98-100 (describing how repeat players in litigation accrue advantages through reputation building opportunities across multiple suits and through interest and investment in rules governing particular outcomes).

66 Nagareda, supra note 22, at 659.

67 See Grundfest \& Huang, supra note 55, at 1312 (noting that a procedural rule that causes litigation costs to be front-loaded will reduce a lawsuit's value because a claimant must incur larger expenses before gaining the advantage of the information disclosed at the end of the first stage of the litigation).

68 See, e.g., Lucian Arye Bebchuck \& Howard F. Chang, The Effect of Offer of Settlement Rules on the Terms of Settlement, 28 J. LEGAL STUD. 489, 510 (1990) ("[S]ettlement terms ... 
Asymmetrical cost imposition is usually most pronounced during the discovery process. In general, access to discovery is granted without limitation once a motion to dismiss is denied, enabling claimants to impose significant, asymmetric production costs on the opposing party. ${ }^{69}$ Moreover, claims that barely survive a motion to dismiss generally trigger the same discovery entitlements as claims that are more likely to succeed. Accordingly, a claimant will obtain a "motion to dismiss premium" in proportion to any temporal or absolute asymmetrical cost imposition in the discovery stage. ${ }^{70}$

The plenary discovery process also enables the imposition of significant asymmetric costs upon plaintiffs. ${ }^{71}$ Defendants can exploit the broad relevance standard under Rule 26(b) by inundating plaintiffs with information, ${ }^{72}$ forcing them to drink from a fire hose-as if to say, "Be careful what you ask for." This is likely to be particularly acute in situations where plaintiffs need discovery the most, because they do

tend to favor the party with lower litigation costs."); Samuel Issacharoff \& George Loewenstein, Unintended Consequences of Mandatory Disclosure, 73 TEX. L. REV. 753, 768-71 (1995) (describing how asymmetric costs in the discovery process increase the bargaining power of the party imposing those costs).

69 See, e.g., Beisner, supra note 52, at 548 (illustrating the incentives that encourage the imposition of excessive discovery costs); Easterbrook, supra note 52, at 637 (pointing out that even the threat of discovery costs will have a meaningful impact on settlement terms); Moss, supra note 52, at 909 (citing concerns that excessive discovery "induces settlement by imposing high costs on defendants"); Doubles A. Rennie, The End of Interrogatories: Why Twombly and Iqbal Should Finally Stop Rule 33 Abuse, 15 LEWIS \& CLARK L. REV. 191 (2011) ("[Interrogatories] are highly susceptible to abuse because it is so easy to impose costs on an adversary with them."). But see Linda S. Mullenix, The Pervasive Myth of Pervasive Discovery Abuse: The Sequel, 39 B.C. L. REv. 683 (1998) (arguing that discovery is not a tool of abuse given how rarely it is used and how minor a burden it usually imposes).

70 The Supreme Court was sensitive to the imposition of asymmetric discovery costs on defendants when it ushered in a new "plausibility" pleading standard in Twombly. 550 U.S. at 559 ("[T]he threat of discovery expense" can lead "cost-conscious defendants to settle even anemic cases before reaching those proceedings"). However, this indirect regulation of discovery through pleading may do little to cure the imposition of asymmetrical costs. See infra Parts II.A.2 and III.A.2 (explaining this risk).

71 See generally William B. Rubenstein, The Concept of Equality in Civil Procedure, 23 CARDozo L. REV. 1865, 1882 (2002) ("[L]iberal discovery can also work against poorer litigants [who] can be flooded with discovery requests.").

72 See Cabraser, supra note 64, at 32 (describing how defendants can use discovery procedures, "with extremely [sic] effectiveness, as an offensive weapon, not simply a defensive shield," to "financially exhaust their opponents in the initial discovery stages of a complex case long before ever reaching the point at which discovery of key material information becomes imminent and inevitable"). Cabraser quotes one defense attorney as saying "[t]he aggressive posture we have taken regarding depositions and discovery in general continues to make these cases extremely burdensome and expensive for plaintiffs' lawyers, particularly sole practitioners." Id. at 22. Strikingly, that same defense attorney went on to say that "[t]o paraphrase General Patton, the way we won these cases was not by spending all of [RJR Tobacco's]'s [sic] money, but by making that other son of a bitch spend all of his." Id. 
not know enough about defendants' internal workings or documents to craft narrower requests. Many plaintiffs may simply buckle under the sheer volume of information and the costs of sifting through it. Existing ex post mechanisms for policing "abusive" discovery practices do little to correct either of these distortions of settlement outcomes. ${ }^{73}$ As a result, the Federal Rules' principle of "liberal" discovery can obscure rather than reveal the merits.

Finally, the Supreme Court's plausibility pleading standard under Bell Atlantic Corp. v. Twombly, cemented in Ashcroft v. Iqbal, imposes new cost asymmetries against plaintiffs at the pleading stage of litigation. The plausibility test now requires plaintiffs to expend potentially significant additional investigatory resources to formulate allegations simply to get into court. ${ }^{74}$ Those additional costs typically do not lead to any incremental disclosure of facts by defendants, who need not even deny the truth of those allegations in moving to dismiss. ${ }^{75}$ The effect on settlement outcomes could well be a systematic shift downward in the value of plaintiffs' claims in all cases-not just those in which plaintiff might reasonably obtain relevant factual information prior to discovery ${ }^{76}$ - in line with the asymmetrical litigation costs associated with the invigorated motion to dismiss. ${ }^{77}$ And those costs may not be trivial, given defendants' increasing tendency to file complex, lengthy Twombly motions that exploit claimants' informational disadvantages. ${ }^{78}$ Consequently, the costs generated by the new heightened pleading standard could cause distortions in settlement valuations or, worse yet, serve as an outright barrier to entry to the federal courts.

b. Informational Imbalances

Informational imbalances also can have an impact on settlement values. As early law and economics models recognized, these asymmetries can prevent the convergence of the parties' settlement

73 See supra Part II.A.1.a.

74 See, e.g., Miller, From Conley, supra note 2, at 67-68 (noting the added investigatory requirement at the pleading stage imposed upon claimants by Twombly).

75 See Twombly, 550 U.S. at 572 (Stevens, J., dissenting) (noting that the Twombly complaint was dismissed "without so much as requiring [defendants] to file an answer denying that they entered into any agreement").

76 See infra Part III.A.1.

77 See Grundfest \& Huang, supra note 55, at 1312 (finding that a plaintiff's option to settle or continue with the litigation decreases in value with greater litigation costs, and decreases more rapidly if those costs are front-loaded).

78 See infra note 84 and accompanying text (explaining the problems of selective judicial notice). 
ranges. ${ }^{79}$ Although the Federal Rules contain some mechanisms for curing informational asymmetries-specifically rules providing for liberal pleading and discovery-they remain largely insensitive to the distortive effect on settlement values generated by parties' strategic exploitation of those imbalances for settlement gain. ${ }^{80}$

The current discovery rules largely tolerate, and to some degree amplify, strategic incentives to exploit informational imbalances. In a world of complex, high-stakes cases, existing discovery mechanisms provide defendants with opportunities to obscure key facts through voluminous production and through aggressive use of privilege and work product doctrine arguments. Defendants also can delay the production of critical documents and information in order to prolong informational asymmetries (and increase the associated asymmetrical temporal costs discussed above). The Federal Rules' tendency toward limited and informal judicial supervision of discovery does little to curb defendants' exploitation of informational asymmetries and accordingly permits the shift of settlement values downward in response to strategic discovery behavior.

In addition, the heightened plausibility pleading requirement for plaintiffs, ${ }^{81}$ combined with the fact that defendants need not even deny the truth of the allegations at the motion to dismiss stage, ${ }^{82}$ means that the defendant will enter the next stage of litigation with information about how the claimant is likely to proceed through the litigation and with a corresponding advantage at the bargaining table. More fundamentally, the heightened pleading standard, in combination with informational disadvantages to which plaintiffs may be subject prior to any discovery, creates a risk that plaintiffs will plead too much in an attempt to survive the motion to dismiss and unwittingly plead themselves out of court. ${ }^{83}$

79 Bebchuk, supra note 55, at 404.

80 See generally Rubenstein, supra note 71, at 1876-81 (noting that equalizing information available to each side in a lawsuit can help generate "greater equipage equality," which "helps ensure the accuracy ... of adjudicated outcomes").

81 The heightened "plausibility" pleading standard was introduced by the Supreme Court in Bell Atlantic Corp. v. Twombly, in which the Court held that a complaint must contain "enough facts to state a claim to relief that is plausible on its face." 550 U.S. 544, 570 (2007). In introducing this standard, the Court in Twombly rejected the long-standing pleading standard articulated in Conley v. Gibson, where the Court held that "a complaint should not be dismissed for failure to state a claim unless it appears beyond doubt that the plaintiff can prove no set of facts in support of his claim." 355 U.S. 41, 45-46 (1957) (emphasis added); Twombly, 550 U.S. at 563 (noting that the Conley standard "has earned its retirement" and that Conley's "no set of facts" language "is best forgotten as an incomplete, negative gloss on an accepted pleading standard").

82 See supra note 75 and accompanying text.

83 See, e.g., U.S. Gypsum Co. v. Ind. Gas Co., 350 F.3d 623, 626 (7th Cir. 2003) ("A litigant 
Defendants can also exploit informational imbalances at the pleading stage in Twombly motions. When armed with superior information, defendants are well equipped to attack the "artfulness" of the relevant pleading, tripping up claimants who may plead facts that, in light of information of which defendants are uniquely aware, the opposing party can make appear implausible or inconsistent. Defendants can also inject selective facts into the plausibility determination by invoking the judicial-notice mechanism to cast doubt upon the plausibility of plaintiffs' claims ${ }^{84}$ and to make required responsive briefs more costly to produce. This advantage may eliminate or reduce the value of various claims, and can create the precise problem attendant to pleading that the 1938 reformers sought to eliminate-the use of procedural traps, in place of the merits, to dictate outcomes.

\section{c. Variance}

High levels of variance, or unpredictability, in litigation outcomes may also distort settlement values. ${ }^{85}$ As proponents of recent financebased models of litigation have pointed out, the pretrial phase of litigation involves numerous sets of decisions, or options, which are part of a multi-stage investment process. These models have demonstrated that the level of variance in the price of a claim at any given decision point in the litigation can significantly affect settlement outcomes. $^{86}$ In a more or less uncertain litigation environment, variance can emerge, for instance, from the content of the substantive

may plead itself out of court by alleging (and thus admitting) the ingredients of a defense.")

84 See, e.g., Tellabs, Inc. v. Makor Issues \& Rights, Ltd., 551 U.S. 308, 322 (2007) ("Courts must consider... other sources courts ordinarily examine when ruling on Rule 12(b)(6) motions to dismiss, in particular ... matters of which a court may take judicial notice."); see also Reply Brief for Appellants at 20 n.10, Minn-Chem, Inc. v. Agrium Inc., 683 F.3d 845 (7th Cir. 2012) (No. 08-cv-6910).

85 See, e.g., In re Rhone-Poulenc Rorer, Inc., 51 F.3d 1293, 1299 (7th Cir. 1995) (Posner, J.) (noting the concern of "forcing the[] defendants to stake their companies on the outcome of a single jury trial, or be forced by fear of the risk of bankruptcy to settle even if they have no legal liability"); Lauren N. Fromme, Unreliable Securities for Retirement Income Security: Certifying the ERISA Stock-Drop Loss, 64 VAND. L. REV. 301, 311 n.53 (2010) ("The "high variance' associated with class-action litigation stems from the possibility of having one enormous, aggregate verdict, as opposed to seeing losses spread out across multiple jurisdictions."); Richard A. Nagareda, Aggregate Litigation Across the Atlantic and the Future of American Exceptionalism, 62 VAND. L. REV. 1, 30 (2009) (noting that settlement pressure increases along with increases in variance).

86 See Grundfest \& Huang, supra note 55, at 1276-78. For additional finance-based models of litigation, see generally Rhee, A Price Theory, supra note 61, where the author constructs a pricing theory for legal disputes, and Robert J. Rhee, The Effect of Risk on Legal Valuation, 78 U. CoLo. L. REv. 193 (2007) [hereinafter Rhee, The Effect of Risk], where the author argues that lawsuits should be viewed as assets. 
law, like a statute containing a treble damages provision; from the option to proceed to a new procedural stage in the litigation, like the option upon a denial of summary judgment to proceed to trial or the option, after culling through materials produced in in a period of discovery, either to gather additional information or not (and possibly then settle); or from the option to proceed through litigation as a certified class. ${ }^{87}$

High levels of variance in potential outcomes at any given point in litigation can shift settlement values upward, ${ }^{88}$ because a defendant, the primary bearer of variance-related risk, may choose to offload that risk through a settlement, priced in accordance with some calculation of expected value, plus an offloading premium in plaintiff's favor. ${ }^{89}$ This effect of variance on settlement values can be further magnified by common cognitive biases: Litigants tend to be risk-averse when faced either with gains of moderate-to-high probability or with losses of low probability; conversely, they tend to be risk-seeking in response to low-probability gains or moderate-to-high-probability losses. ${ }^{90}$

Judicial interpretations of certain Rules are sensitive to some degree to the possibility that variance can shift settlement values upward for reasons unrelated to the merits. Variance concerns underlie in part the Supreme Court's decisions in the summary

87 See Grundfest \& Huang, supra note 55, at 1317 (tracing how variance can emerge from changes in and use of both substantive and procedural rules).

88 Id. at 1276. This effect depends in part on a plaintiff's ability to reduce her litigation expenditures sufficiently in case the lawsuit goes poorly from her perspective. Id. at 131516.

89 The paradigmatic example of this phenomenon is the settlement that typically follows the certification of a class action. The potential risk of a class-wide verdict (variance) is often too large for the defendant to bear, so the defendant offloads the risk through settlement. However, the extent to which the certification of a class action exerts such a high level of settlement pressure as to be tantamount to "blackmail" - a charge levied by Judges Easterbrook, Friendly, and Posner-is debatable. See Charles Silver, "We're Scared to Death:" Class Certification and Blackmail, 78 N.Y.U. L. REv. 1357, 1359 (2003) ("[Many academics and] [e]mpirical researchers ... dispute the blackmail claim.").

90 Rachlinski, supra note 56, at 130-60. Some studies indicate that attorneys can mitigate these effects and lead clients to take a more risk-neutral approach to litigation decisions. Russell Korobkin \& Chris Guthrie, Psychology, Economics, and Settlement: A New Look at the Role of the Lawyer, 76 TEx. L. REv. 77, 120 (1997) (using a psychology experiment to support this conclusion). That said, the presence of a contingency fee arrangement on the plaintiffs' side can actually accentuate these risk preferences by enabling the lawyer herself to be more risk-seeking on a specific case among a larger portfolio of cases. See Stephen C. Yeazell, Refinancing Civil Litigation, 51 DePAUL L. REv. 183, 200 (2001) (explaining that law firms give attorneys the flexibility to pursue a combination of both high-payout, high-risk cases and low-risk, stable-payout cases); see also Jane Goodman-Delahunty et al., Insightful or Wishful: Lawyers' Ability To Predict Case Outcomes, 16 PSYchol. PUB. POL'Y \& L. 133, 143 (2010) (finding that a majority of lawyers are susceptible to overconfidence). 
judgment trilogy, ${ }^{91}$ and they have additional, though less explicit, explanatory power in Twombly. Such concerns also underlie recent court of appeals decisions requiring a putative class to satisfy the requirements for class certification under Rule 23 by a preponderance of the evidence, even if such an inquiry overlaps with merits-related questions. $^{92}$ However, with perhaps the limited exception of the emerging trend toward more robust merits-based analysis at the class certification stage, pretrial screening mechanisms like the summary judgment stage and the motion to dismiss stage only eliminate upward-shifting variance by screening out clearly meritless cases. These binary mechanisms are not designed to narrow the potential range of outcomes on surviving claims. Nor are they designed to provide robust merits-based information about those claims, much less at early stages in the litigation, when parties typically seek to manage variance. ${ }^{93}$

High levels of variance can also, indirectly, incentivize defendants to make strategic "zero" settlement offers, ${ }^{94}$ perhaps in combination with other strategic behavior vis-à-vis current procedural rules, in order to shift settlement ranges downward for reasons bearing little relationship to the merits. Of course, defendants may make zero offers for a number of reasons. ${ }^{95}$ But in the face of potentially expansive liability, say, in cases of mass harm or in cases involving high potential

91 See Nagareda, supra note 22, at 651 ("Viewed with the aid of our scholarly vocabulary today, the debates over the various pretrial checkpoints [such as summary judgment] center on what one might label as uncertainty costs [like] variance of outcomes associated with movement to successive stages of the litigation process.").

92 See In re Hydrogen Peroxide Antitrust Litig., 552 F.3d 305, 320, 324 (3d Cir. 2008) ("An overlap between a class certification requirement and the merits of a claim is no reason to decline to resolve relevant disputes when necessary to determine whether a class certification requirement is met."); In re Pub. Offering Sec. Litig., 471 F.3d 24, 37 (2d Cir. 2006) (establishing a preponderance of the evidence standard for class certification).

93 Parties tend to manage variance in lawsuits, as they do in finance, ex ante. Rhee, The Effect of Risk, supra note 86, at 230 (explaining that parties, by necessity, make decisions ex ante).

94 Gross \& Syverud, Getting to No, supra note 59, at 343 (explaining that a zero settlement offer is one in which the defendants refuse to make any settlement offer).

95 For instance, zero offers may be attributable to problems of litigation costs and informational asymmetries; a defendant may make such offers in order to proceed to trial, where she seeks vindication. See Robert G. Bone, Modeling Frivolous Suits, 145 U. PA. L. REv. 519, 591-92 (1997) [hereinafter Bone, Modeling Frivolous Suits] (discussing impediments to settlement of litigation over penalties for frivolous suits). An insured defendant, who faces little risk as a practical matter of paying more than its insurance policy limit, may rationally make a zero offer simply to drive down the payout in light of plaintiffs' particular levels of risk tolerance and resources. See, e.g., Charles Silver et al., Physicians Insurance Limits and Malpractice Payments: Evidence from Texas Closed Claims, 1990-2003, 36 J. LEGAL STUD. S9, S10 (2007) (finding that only $1.5 \%$ of paid malpractice claims involved payments that exceeded the primary policy limits). 
damages, defendants may react not by offloading the risk of variance through settlement, but by making zero offers ${ }^{96}$ for strategic reasons. ${ }^{97}$ In particular, defendants facing multiple claims for similar harms may exploit plaintiffs' risk aversions, which are especially pronounced for those plaintiffs with limited resources, by taking a hard-line approach to settlement. ${ }^{98}$ Such offers might even be conceptualized as a form of vigilante procedural reform: To the extent pretrial procedural mechanisms insufficiently inform parties about the merits of the underlying claims so as to better narrow the range of potential outcomes, zero offers can be conceptualized as a market responsealbeit a normatively undesirable one in cases in which claims are in fact meritorious.

\section{Faint Shadows: Pretrial Procedures Fail To Provide Parties with Robust Merits-Related Guidance for Settlement}

Settlement outcomes that do not meaningfully reflect the merits of the underlying claims are not just the product of factors that are unrelated to the merits of a case and insufficiently mitigated by the Federal Rules. Here I argue that they are also the product of at least three structural features of the Federal Rules themselves. First, pretrial adjudicative determinations under the Federal Rules, by design, produce limited merits-based guidance for settlement decisions. Second, more robust merits-based determinations are deferred until or around the time of trial itself. Third, even those pretrial procedures that provide limited merits-based guidance sometimes fail on their own terms. Each of these structural features contributes to the fading influence of substantive law on settlement outcomes.

96 Zero offers are not as rare as early litigation models, such as the Priest-Klein hypothesis, would predict; in 1991, they were found to occur in $25.2 \%$ of personal injury cases and in $44 \%$ of commercial transaction cases. Gross \& Syverud, Getting to No, supra note 59 , at 343 .

97 See id. at 343 (noting that zero offers are used for the strategic purposes of inducing dismissal through threatened higher trial costs, dissuading risk-averse plaintiffs from proceeding further with litigation, and discouraging future litigation by different plaintiffs).

98 This was the strategy that Merck employed at the outset of suits brought by various plaintiffs alleging that its drug Vioxx caused heart attacks and strokes. See generally Howard M. Erichson \& Benjamin C. Zipursky, Consent Versus Closure, 96 CoRnELL L. REV. 265, 270-71 \& n.12 (2011) (noting that Merck initially insisted that it would take each and every case to trial, but also speculating that "early trials and procedural battles may be seen as fights over bargaining position for the all-but-inevitable mass settlement"). Merck then took various cases to trial, using the results as guideposts for a global settlement of Vioxx claims. See generally id. at 278-80 (describing how the 2007 Vioxx settlement was reached). 
a. Pretrial Adjudicative Procedures Generate Limited Merits Guidance

Pretrial adjudicative procedures are designed to determine whether claims satisfy a minimum standard of viability sufficient to allow them to move onto the next stage of the litigation. The 1938 reformers designed these mechanisms with the purpose of preventing the expenditure of resources-by litigants or the judicial system-on claims that were so insupportable as not to justify the cost of discovery (motions to dismiss) or trial (summary judgment). This approach makes sense from within the 1938 worldview: When the structural litigation endpoint is resolution through trial, it is sensible for pretrial adjudicative procedures to serve a gatekeeping function in determining whether a given claim should, in fact, proceed to the next step on the path toward trial. Moreover, by design, judges are limited under these rules in their ability to apply law to facts. ${ }^{99}$ Pretrial adjudicative mechanisms are not designed to give parties guidance, particularly on issues that may be more salient to settlement decisions, and in practice provide only weak signals as to whether the claim is meritorious. ${ }^{100}$

The limitations of current pretrial adjudicative mechanisms to provide merits-based guidance for settlement can be illustrated by an example: the measure of damages, which clearly has a significant influence on settlement outcomes. The fact that courts are limited to adjudicating the merits of cases in the context of case-dispositive motions at the pretrial stage typically will prevent courts from focusing on legal issues that exert significant influence on settlement decisions but will not resolve the entire dispute. Thus, to the extent the parties disagree on the appropriate legal measure of damages, that issue likely will not be addressed by the court until or just before trial-for example, in resolving a motion in limine to exclude an expert witness or in resolving the parties' dispute over proposed jury instructions. Moreover, to the extent the parties disagree factually on the amount of damages, limitations on courts' ability to resolve factual disputes at an

99 That said, scholars have noted that the bright line between questions of law and fact under the Federal Rules is fading. See, e.g., Richard A. Epstein, Bell Atlantic v. Twombly: How Motions to Dismiss Become (Disguised) Summary Judgments, 25 WASH. U. J.L. \& PoL'y 61, 72 (2007) (pointing out that the "rigid division between fact and law that [appears] to be built into the Federal Rules" has long been eroding).

100 See, e.g., Jonathan T. Molot, How Changes in the Legal Profession Reflect Changes in Civil Procedure, 84 VA. L. REv. 955, 988-94 (1998) [hereinafter Molot, Changes in the Legal Profession] (arguing that issue-narrowing is inadequately addressed through summary judgment due to evolving summary judgment standards and institutional obstacles in sifting through issues within a case). 
early stage hamper their ability to provide the parties with guidance on that settlement-salient but non-dispositive issue.

For claims that are not so weak as to be screened out of the system, current pretrial adjudication mechanisms fail to provide meaningful merits-based guidance, instead serving as procedural obstacles that, once overcome, increase the parties' settlement ranges. For instance, if a claim survives a summary judgment motion or a motion to dismiss, both parties will raise settlement estimations. ${ }^{101}$ Or at the very least, the nonmovant's settlement demands will increase following such denials, particularly given the psychological tendency of litigants to try and recoup sunk costs. ${ }^{102}$ However, these procedures are not designed to distinguish those claims that the nonmovant maintains because of their strength on the merits and those it maintains because they are just strong enough to pass through the relevant procedural tollbooth. ${ }^{103}$ In short, allowing a claim to proceed beyond the motion to dismiss or summary judgment stage shifts the existing settlement range upward but does little to inform the width of that settlement range.

b. Robust Merits Evaluation Occurs Too Late in the Litigation Process To Influence Settlement Outcomes

Many of the mechanisms designed to generate meaningful merits evaluation often arrive too late to enrich the parties' understanding of the strength of their claims before the case settles. For example, no procedural checkpoint in the Federal Rules situated prior to trial, save perhaps an emerging preponderance-of-the-evidence requirement at the class certification stage, ${ }^{104}$ permits evaluation of evidence. In fact,

101 This will be true more often, in the case of summary judgment, if any impending trial is to be conducted by a judge rather than a jury. Issacharoff \& Loewenstein, supra note 31 , at 99 n.116. It will be less true, either for summary judgment or a motion to dismiss, if the judge's denial of a motion signals a likelihood of the movant on various upcoming motions in either the discovery or trial stage of litigation. These signals may become more frequent, and perhaps stronger, in the wake of 2010 amendments to Rule 56, which require judges to explain a denial of a motion for summary judgment. FED. R. CIV. P. 56(a).

102 The "sunk cost" fallacy is a psychological phenomenon whereby individuals incur further losses and/or take substantial risks in order to recoup prior losses. See, e.g., Hersh Shefrin \& Meir Statman, The Disposition To Sell Winners Too Early and Ride Losers Too Long: Theory and Evidence, 40 J. Fin. 777, 789-90 (1985) (describing "sunk costs" in the context of stock and mutual fund sale decisions).

103 See Molot, Changes in the Legal Profession, supra note 100, at 992 (discussing, in particular, summary judgment).

104 See, e.g., Wal-Mart Stores, Inc. v. Dukes, 131 S. Ct. 2541, 2551 (2011) ("Rule 23 does not set forth a mere pleading standard. A party seeking class certification must affirmatively demonstrate his compliance with the Rule-that is, he must be prepared to prove that there are in fact sufficiently numerous parties, common questions of law or fact, etc."). 
the summary judgment standard explicitly prohibits such tasks. ${ }^{105}$ And the most notable mechanism designed in part to provide such information, the summary jury trial, ${ }^{106}$ has largely disappeared-in part because it was unavailable until too late in the litigation process. ${ }^{107}$

Consequently, unless parties proceed to trial-a rare, aberrant choice-evidence in a given case tends to be evaluated in light of the substantive law by no one other than the parties themselves. But parties do so often in the face of legal uncertainty ${ }^{108}$ and under conditions that tend to produce self-serving and frequently disparate assessments of the relevant evidence and law. ${ }^{109}$ Further, even information regarding the viability of claims for a possible trial is often generated too late in the litigation process to inform the parties' settlement decisions. Summary judgment resolves very few cases, ${ }^{110}$ and the summary judgment mechanism comes only after the costs of discovery have exerted settlement pressure.

\section{c. Pretrial Merits-Screening Procedures Sometimes Fail on}

Their Own Terms

In some instances, pretrial screening mechanisms fail even to

105 See Anderson v. Liberty Lobby, Inc., 477 U.S. 242, 255 (1986) ("Credibility determinations, the weighing of the evidence, and the drawing of legitimate inferences from the facts are jury functions, not those of a judge, whether he is ruling on a motion for summary judgment or for a directed verdict.").

106 See, e.g., Harvey G. Brown, The Summary Jury Trial: Perspectives of Bench and Bar, 38 Hous. LAW. 32, 33 (2001) (describing the summary jury trial as a mock trial with a real judge and jury but with a non-binding verdict). Critics, most prominently Judge Posner, have also argued for "hesitation" in the use of summary jury trials that enlarge jury service. See Richard A. Posner, The Summary Jury Trial and Other Methods of Alternative Dispute Resolution: Some Cautionary Observations, 53 U. CHI. L. REv. 366, 386 (1986).

107 The summary jury trial is "employed as a 'last resort' [and] most effectively conducted on the eve of trial after discovery is completed, litigation strategy is fully developed, and other settlement attempts have failed." See Brown, supra note 106, at 33. Of course, lawyers can and do conduct "mock jury" trials, but they tend to do so just before a case would go to trial.

108 See, e.g., Lynn M. LoPucki, Legal Culture, Legal Strategy, and the Law in Lawyers' Heads, 90 Nw. U. L. REv. 1498, 1555 (1996) (describing the dissonance between "law on the books" and the more simplified and highly socialized "law in lawyers' heads").

109 While some behavioral studies indicate that attorneys may be less susceptible to selfserving biases than litigants, see for example Korobkin \& Guthrie, supra note 90, at 137, recent studies demonstrate that attorneys are not as adept at producing objective assessments about the strength of their cases as believed, even when various debiasing techniques are employed. See, e.g., Goodman-Delahunty et al., supra note 90, at 135-50 (finding that lawyers are susceptible to overconfidence).

110 The summary judgment mechanism is invoked in a fairly small percentage of cases. See Cecil et al., supra note 31, at 871 (finding that in roughly twelve percent of cases, at least one summary judgment motion is filed). 
generate limited signals about the merits of a case. This is because the screening standards are very general and highly discretionary, and in some jurisdictions or for some types of claims, trends in favor of either granting or denying these pretrial dispositive motions have emerged. ${ }^{111}$ Predictable outcomes weaken even the faint signals generated by these pretrial adjudications for purposes of informing settlement valuation. This is true in the following, albeit reductionist, sense: To the extent settlement values reflect, however roughly, the parties' estimation of the claimants' likelihood of success on the merits, $p,{ }^{112}$ a pronounced trend in favor either of granting (or denying) summary judgment motions or motions to dismiss will decrease (or increase) that value $p$ by some percentage that is related not to the merits, but instead to the trend itself.

For instance, trends in favor of denials can give claimants a summary judgment or a motion to dismiss "premium," prior to and with little consideration to the likelihood of success on those motions. ${ }^{113}$ Conversely, when litigation takes place in jurisdictions or before judges known for frequently granting such motions, ${ }^{114}$ the strength of the limited merits-related signals is similarly weakened, but settlement values will shift systematically downward, rather than upward. Unless the party disadvantaged by the particular trend is willing to gamble on an expensive, drawn-out, and uncertain appeal (and the paucity of reported appellate opinions suggests that parties may not typically be so able or inclined ${ }^{115}$ ), such predictability vitiates the credibility of that party's threat to proceed successfully through pretrial adjudicatory stages. ${ }^{116}$

111 This reality is well understood among lawyers and has empirical support. See Charlotte L. Lanvers, Different Federal District Court, Different Disposition: An Empirical Comparison of ADA, Title VII Race and Sex, and ADEA Employment Discrimination Dispositions in the Eastern District of Pennsylvania and the Northern District of Georgia, 16 CORNELL J.L. \& PUB. POL'Y 381, 382 (2007) (citing empirical evidence demonstrating "[d]ifferences in case dispositions [that] appear to depend on the district court studied").

112 For a more in-depth discussion of the standard economic model used to analyze settlement negotiations, see Rhee, The Effect of Risk, supra note 86, at 201.

113 See Robert G. Bone, Who Decides? A Critical Look at Procedural Discretion, 28 CARdozo L. REv. 1961, 1980 (2007) [hereinafter Bone, Who Decides?] (noting that when judges have a reputation for frequently denying motions for summary judgment, parties will internalize that fact long before the summary judgment stage).

114 See Bone, Regulation of Court Access, supra note 6, at 889-90 (noting that judges may over screen cases at the motion to dismiss stage because of docket pressures).

115 See Edward Brunet, Six Summary Judgment Safeguards, 43 AKRon L. REv. 1165, 1183 (2010) ("Modest quantities of summary judgment appeals suggest that the reported case law fails to reflect a representative set of issues.").

116 See Grundfest \& Huang, supra note 55, at 1272-80 (describing the effect of predictability and uncertainty regarding likely case outcomes on parties' negotiating positions). 
Further, trends in favor of granting pretrial motions transform what might be acceptable transaction costs-acceptable in the sense that they are directed at generating merits-based information about the case-into costs that simply chill otherwise meritorious claims. What is troubling, from a policy perspective, is not just the trend's shifting of settlement values downward, but also its shifting of claims out of the federal courts completely, which will be more pronounced in areas of the law characterized by typically under-capitalized plaintiffs on the one hand, and repeat-player defendants, motivated to expend resources on that motion disproportionate to the stakes of the case, ${ }^{117}$ on the other.

Predictable trends in the granting or denying of pretrial motions have also emerged with regard to specific types of claims, again with the effect of skewing settlement values in correspondence with those categorical tendencies. For instance, some claims are known for being treated with "kid gloves" for purposes of summary judgment, meaning that a denial of summary judgment is more likely than it would be in cases involving different types of claims. ${ }^{118}$ Such trends increase the nonmovant's credibility to succeed on such a motion without a corresponding evaluation of the merits of a particular case, thus shifting systematically settlement ranges attendant to those types of claims upward. ${ }^{119}$ Moreover, if a judge, contrary to that general trend, grants in part the motion for summary judgment, the settlement value of the surviving claims will likely plummet to some degree more significantly than it otherwise would in a jurisdiction not characterized by such a trend because of the merits-based signal. Conversely, empirical studies reveal that for other types of claims-particularly, for instance, employment discrimination and civil rights claimssummary judgments and motions to dismiss are disproportionately granted. ${ }^{120}$ The effect of such trends will be to shift settlement ranges

117 See Issacharoff \& Loewenstein, supra note 31, at 109-10 (describing how repeatdefenders can dissuade future suits by establishing threat credibility through costly pretrial motions in all cases, even when the stakes in particular cases do not warrant them).

118 Such trends have emerged, for example, in the context of the Federal Employers Liability Act (FELA). See, e.g., Rogers v. Mo. Pac. R.R., 352 U.S. 500, 506 (1957) (noting that, under the FELA, "the test of a jury case is simply whether the proofs justify with reason the conclusion that employer negligence played any part, even the slightest, in producing the injury").

119 See, e.g., Lanvers, supra note 111, at 398-99 (finding that local preferences for summary judgment impact settlement decisions more than changes to the substantive law do).

120 See, e.g., Raymond H. Brescia, The Iqbal Effect: The Impact of New Pleading Standards in Employment and Housing Discrimination Litigation, 100 Ky. L.J. 235, 239-40 (2011) (reporting that post-Iqbal, employment and housing discrimination claims are being dismissed at accelerated rates); Patricia W. Hatamyar, The Tao of Pleading: Do Twombly and 
systematically downward in line with the relevant trend, rather than with the merits of a given case. Such effects, troublingly though unsurprisingly, will be more pronounced the more impecunious the claimants.

\section{d. Scarce Trials and Current Pretrial Managerial Judging}

Practices Do Not Cure These Problems

In a world in which the Rules of Civil Procedure that actually generate merits-based guidance often boil down to Rules 12 and 56, a distorted settlement market has emerged. Moreover, two features of the procedural regime to which we might look to right the ship-the few trials that remain and managerial judging through settlement conferences under Rule 16-do not show sufficient promise to remedy these problems. Indeed, they may only further steer the ship off course.

As for trials, the vanishing rate of trials means that trial outcomes may not generate sufficient signals to create a well-functioning settlement market. Moreover, empirical research reveals that even those cases that do reach trial tend to be unrepresentative. ${ }^{121}$ Thus, to the extent the outcomes of these cases succeed in helping to define the settlement market by guiding settlement values, their outcomes may actually distort those values in more typical cases.

Moreover, although the modern interpretation of Rule 16 evinces a greater attentiveness by rulemakers to the fact that settlement is the endpoint in most cases, ${ }^{122}$ empirical research also reveals that the presentation to the parties of the legal strengths and weaknesses of a

Iqbal Matter Empirically?, 59 AM. U. L. REV. 553, 606 (2010) (finding that constitutional civil rights cases and various labor cases are now more likely to be dismissed by a 12(b)(6) motion than contracts, torts, and other types of cases); Theodore Eisenberg \& Charlotte Lanvers, Summary Judgment Rates over Time, Across Case Categories, and Across Districts: An Empirical Study of Three Large Federal Districts 7-8 (Cornell Law Sch. Research Paper, Paper No. 08-222, 2008), available at http://scholarship.law.cornell.edu/lsrp_papers/108 (finding that employment discrimination and civil rights claims were dismissed on summary judgment far more frequently than contract and tort claims); Memorandum from Joe Cecil and George Cort, Fed. Judicial Ctr., to Judge Michael Baylson 3, 8-9 (Aug. 13, 2008), http://www.uscourts.gov/uscourts/RulesAndPolicies/rules/sujulrs2.pdf (making similar findings).

121 See Gross \& Syverud, Don't Try, supra note 24, at 4, 6 (finding that the cases that go to trial generally involve a combination of contingent fee arrangements, extensive insurance policies that cover the cost of defending all or some of the potential damages, personal injury claims, and particularly odd facts); Richard Delgado et al., Fairness and Formality: Minimizing the Risk of Prejudice in Alternative Dispute Resolution, 1985 WIS. L. REV. 1359, 1395-96, 1399 (noting that claimants who take cases to trial may be unusually interested in obtaining formalized justice).

122 See generally David L. Shapiro, Federal Rule 16: A Look at the Theory and Practice of Rulemaking, 137 U. PA. L. REv. 1969, 1984 (1989) ("The role of the judge . .. was to keep cases moving at a reasonable pace, and to see that cases not be needlessly tried."). 
given case-long thought to be the hallmark of settlement conferences-plays a surprisingly small role in the sorts of settlement conferences for which Rule 16 calls. ${ }^{123}$ Nonetheless, judges report that they exert heavy pressure on parties to settle-influence that appears to be motivated by factors unrelated to the merits of the case, including, primarily, the belief that settlement generally is in the parties' best interests; secondarily, a sense of accomplishment at having settled a case; and thirdly, to some degree, the desire to clear dockets. ${ }^{124}$

Of course, the introduction of more systematic guidelines for discussing the merits during settlement conferences might improve matters on this score. That said, even if managerial judging techniques under Rule 16 were harnessed for the express purpose of injecting a discussion of the merits into settlement negotiations, such techniques would still occur in a highly discretionary and nontransparent manner. ${ }^{125}$ Moreover, judges are poorly situated, as an institutional matter, to bring about systematic changes along these lines. ${ }^{126}$ Indeed, and particularly to the extent that injecting the merits into parties' settlement calculations may call for different procedural rules in different contexts, ${ }^{127}$ such policy-laden decisions are best made systematically, by the Rules Advisory Committee or Congress, rather than through ad hoc and nontransparent managerial judging.

In sum, the state of the world of settlement under our current

123 See Robinson, supra note 39, at 126 (reporting that only twenty-three percent of general jurisdiction judges claimed that they used this "technique" in ninety percent of their settlement conferences and that twenty percent of judges reported using it in less than forty percent of their conferences; reporting also that among judges who settle a proportionately higher number of their cases, about a fifth report using this technique more than ninety percent of the time and an approximately equal number report using it less than ten percent of the time). To be clear, Robinson surveyed state judges, not federal judges. Id. at 114-15. Further empirical work regarding various approaches federal court judges apply in settlement conferences is needed. However, the information about state court judges is consistent with the focus of procedural and legislative reforms regarding settlement of federal cases, which have focused on bringing about settlement quickly.

124 See Robinson, supra note 39, at 143-46 (reporting that judges' biggest motivation for influencing parties to settle is that they believe that settlement is in the parties' best interests; that roughly seventy-five percent of all judges are also motivated by a desire to settle hard cases; and that roughly thirty-three percent of general civil judges (as opposed to family law judges) are motivated by a desire to clear crowded dockets in more than half of their cases).

125 See, e.g., Molot, An Old Judicial Role, supra note 43, at 40-41 (noting that managerial judging is not uniform); Resnik, supra note 37, at 378 ("Managerial judges frequently work beyond the public view, off the record, with no obligation to provide written, reasoned opinions, and out of reach of appellate review.").

126 See generally Molot, An Old Judicial Role, supra note 43, at 41-43 (noting that managerial judging departs from the "traditional" role of the judge).

127 See infra Part III.A.3. 
procedural regime should give us pause about the extent to which our procedural rules are providing parties with meaningful merits-based information for purposes of guiding settlement decisions. Indeed, there is reason to suspect that settlement negotiations carried out under the current Federal Rules and purportedly conducted in the shadow of the governing law may not be meaningfully influenced by that law. And, as the next subpart will show, the situation could be getting worse: As the shadow that laws cast over case outcomes is growing faint, a new shadow - the shadow of settlement-is emerging.

\section{B. Eclipsing the Shadow of the Law: Settlements in the Shadow of Settlement}

A different reality of modern litigation threatens to distort settlement outcomes even further. Increasingly, without trial outcomes to guide settlements, parties look to outcomes of prior settlements to guide their judgments about settlement values. This trend of bargaining in the shadow of settlement has only begun to receive attention in the empirical literature. But the trend is an important aspect of the problem facing modern litigation because it tends to amplify the distortions of the settlement market outlined in Part II.A. Prior settlement outcomes, which suffer from all of the distortions detailed above, can now propagate those distortions insofar as they influence future settlement outcomes. ${ }^{128}$

The notion that settlements cast a meaningful shadow on future case outcomes runs contrary to the conventional account of settlement. Judges, legislators, and scholars have long criticized settlement for its secretive nature. ${ }^{129}$ Concerns about settlements' secrecy, and more specifically, parties' ability to purchase that secrecy at the expense of the public, have led a number of federal district courts to restrict the use of sealed settlement agreements. ${ }^{130}$ Scholars continue to debate

128 Indeed, settlement outcomes may even influence jurors' perceptions of right and wrong, and perhaps even their verdicts, as exemplified by the few remaining trials in our modern world of litigation. See Depoorter, supra note 7, at 957, 978.

129 See, e.g., Resnik, supra note 41, at 803 (noting that the rise of settlement and alternative dispute resolution has reduced the impact of the "public processes of courts," which "contribute to the functioning of democracies and give meaning to democratic precepts that locate sovereignty in the people, constrain government actors, and insist on the equality of treatment under law"); Fromm, supra note 42, at 663 ("[M] ost information about settlement remains hidden behind confidentiality agreements and sealed court records."); Gross \& Syverud, Don't Try, supra note 24, at 4 (describing settlements as "invisible"). Perhaps the most famous critique of settlement, set forth by Owen Fiss, laments, among other things, that settlement fails to produce public pronouncements of the law. See Fiss, supra note 5, at 1089-90.

130 For example, the U.S. District Court for the District of South Carolina prohibits the 
whether such reforms are desirable, ${ }^{131}$ particularly in specific categories of cases that may warrant some measure of courtsanctioned secrecy. ${ }^{132}$ Whatever one's normative view, as a descriptive matter, settlement literature largely accepts that information related to a particular settlement remains in the hands of the parties to the dispute. ${ }^{133}$

As an empirical matter, however, secret settlements may not be as pervasive as is commonly thought. For instance, a 2010 study reveals that information about settlements is in fact available to legal professionals through a variety of means: sunshine laws; the oral culture of legal communities, enhanced both by increased judicial involvement in promoting settlements and the rise of large law firms, wherein a great deal of sensitive information is shared among large numbers of attorneys; specialized law reporters, which provide settlement information related to certain injuries, jurisdictions, legal fields, or areas of practice; professional interest organizations, such as

filing of settlements under seal, D.S.C. LoCAL CIV. R. 5.03(E), and the Eastern District of Michigan has adopted a local rule limiting the duration of secret settlement agreements, E.D. MICH. LOCAL R. 5.3. For a survey of federal court local rules addressing sealed records, see

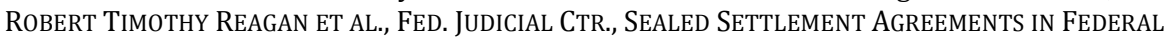
DisTRICT COURT app. at B-1 to -27 (2004), available at http://www.fjc.gov/public/pdf.nsf/lookup/sealset3.pdf/\$file/sealset3.pdf.

131 Compare, e.g., Christopher R. Drahozal \& Laura J. Hines, Secret Settlement Restrictions and Unintended Consequences, 54 U. KAN. L. REv. 1457, 1480-82 (2006) (arguing that sunshine laws and other similar reforms may lead to forum shopping or cause parties to leave the system of litigation altogether), with David A. Dana \& Susan P. Koniak, Secret Settlements and Practice Restrictions Aid Lawyer Cartels and Cause Other Harms, 2003 U. ILL. L. REV. 1217, 1226 ('[T]here are no legitimate interests protected by 'private' secrecy agreements that could not be as well protected by court orders where appropriate.").

132 See Jack H. Friedenthal, Secrecy in Civil Litigation: Discovery and Party Agreements, 9 J.L. \& POL'Y 67, 98 (2000) (suggesting a "presumption of nondisclosure" when courts consider materials that "have not been used at trial or on motion to obtain a substantive decision," but suggesting that the opposite presumption be applied when cases involve "the propriety of the actions of a government entity" or when the materials involved "have been presented at trial... in support of a substantive determination"); Arthur R. Miller, Confidentiality, Protective Orders, and Public Access to the Courts, 105 HARv. L. REv. 427, 48586 (1991) [hereinafter Miller, Confidentiality] (noting that "public access may be important when one of the settling litigants is a governmental agency, public entity, or official, when the settlement is a court-approved class settlement, or when there has been some other significant judicial participation in the process," but concluding that in most cases, "absent special circumstances, a court should honor confidentialities that are bargained-for elements of settlement agreements").

133 See, e.g., Jules Coleman \& Charles Silver, Justice in Settlements, 4 Soc. PHIL. \& PoL'Y 102, 114-15 (1986) (noting that settlement deprives the public of information with regard to the state of the law in the form of judicial opinions and precedents); Friedenthal, supra note 132, at 76-77 (noting that parties can conclude private confidentiality agreements or seek protective orders from the court to guarantee the confidentiality of information); Miller, Confidentiality, supra note 132, at 486-87 (describing the use of confidentiality orders in settlements). 
the American Association for Justice; and, less reliably as a matter of representative sampling, mass media coverage. ${ }^{134}$ According to this study, "lawyers are generally aware of the trends in settlement awards in their field of practice" 135 and judges are likely aware of settlement trends within their districts. ${ }^{136}$ Further, a 2004 FJC study, the most systematic conducted to date, revealed that only $0.44 \%$ of 288,846 civil cases resulted in sealed settlements. ${ }^{137}$ The FJC also found that in ninety-seven percent of the cases with sealed settlement agreements, the complaint was not sealed. ${ }^{138}$

Of course, settlement is by no means a fully transparent process. Many settlement outcomes remain confidential, particularly in cases involving personal injury claims. ${ }^{139}$ Attorneys still attest anecdotally to the use of confidentiality agreements. ${ }^{140}$ Empirical data, particularly regarding the extent to which disputes are settled before cases are filed in court, remains incomplete. ${ }^{141}$ Further, the sources of settlement information are more available to certain parties than to others, ${ }^{142}$ and even where some settlement information is available, there is often more information that remains unavailable to the public. ${ }^{143}$

134 Depoorter, supra note 7, at 966-70.

135 Id. at 971 n.56.

136 See id. at 973 (noting that a majority of lawyers surveyed believed judges to have such an awareness).

137 REAGAN ET AL., supra note 130, at 3, 5. Nevertheless, additional empirical work on this score is needed. The Federal Judiciary Center (FJC) study, though the most systematic study of settlement confidentiality conducted to date, does not evaluate the percentage of Stipulated Motions of Dismissal, which effectively can conceal settlements from the public eye.

138 Id. at 8.

139 See id. at 3, 5 (noting that of the 1270 cases with sealed settlements evaluated by the FJC, thirty percent were personal injury cases).

140 See, e.g., Fromm, supra note 42, at 676 (reporting one defense lawyer's statement that "[he had never] put a settlement together in the past five to six years that [has not contained] a confidentiality clause"); id. at 676 n.53 (reporting the statement of a labor and employment lawyer, who "never settles a private, single-person lawsuit without a confidentiality clause in the settlement agreement").

141 As Chief Judge Joseph F. Anderson of the U.S. District Court for the District of South Carolina noted, "I will concede that the vast majority of cases are settled openly. I would also contend, however, that the number of sealed settlements is greater than the index books or docket sheets would suggest." Joseph F. Anderson, Jr., Hidden from the Public by Order of the Court: The Case Against Government-Enforced Secrecy, 55 S.C. L. REv. 711, 738 (2004).

142 See Fromm, supra note 42, at 700 ("Because some sources of settlement information are better than others, and because the best source of settlement information-the firsthand knowledge of the repeat player-is available to relatively few persons, each participant in a dispute may have a different quantity and quality of settlement information ....").

143 See id. at 680 ("[Because] so many settlements are confidential, published sources and networks are seriously deficient in the amount of settlement information they generate 
Nevertheless, the conventional view of settlements as wholly secret obscures the ways in which publicly available information about settlements increasingly impacts parties' settlement decisions. This trend of using prior settlement outcomes as "precedent" is likely to increase as interested parties turn to electronic databases to guide settlement payouts. The insurance industry has taken the lead in creating and using such databases to calculate settlement ranges ${ }^{144}$ unsurprising, given the heavy influence of insurance coverage in the resolution of disputes. ${ }^{145}$ The two most widely used programs are (1) Colossus, which is employed primarily to determine settlement ranges for personal injury claims by analyzing medical reports to determine treatment options, pain and suffering, and impairment, and (2) Xactimate, which operates much like Colossus, but which is used to calculate settlement ranges in property damage claims. ${ }^{146}$

These settlement databases, at least in their current forms, illustrate the potential problems that bargaining in the shadow of settlement creates for aligning settlement outcomes with the merits of underlying claims. First, settlement in the shadow of settlement creates its own distortive informational imbalances. Whereas litigated outcomes are publicly reported, and thus widely available, repeatplayer litigants, primarily insurers and their attorneys, have begun to build up a virtual monopoly over the information about unreported settlements. This informational monopoly gives those parties bargaining advantages against less informed litigants, enabling the shift of settlement values downward in favor of the insurer, but for reasons bearing little relationship to the merits of the claims. ${ }^{147}$

Second, this informational imbalance allows the parties holding

and are often unreliable tools for case evaluation and negotiation.").

144 There are other electronic sources of settlement information; in particular, some of this information can be found in judgment and verdict databases on legal research sites like Westlaw and LexisNexis. The information in these databases, however, is scattered, limited, and unsystematic.

145 See, e.g., Tom Baker, Blood Money, New Money, and the Moral Economy of Tort Law in Action, 35 LAW \& Soc'Y REV. 275, 280 (2001) (finding a similar trend in personal injury litigation); Baker \& Griffith, supra note 53, at 806 (finding that the majority of securities claims settle within the limits of the defendants' directors' and officers' insurance coverage); Bernard Black et al., Outside Director Liability, 58 STAN. L. REv. 1055, 1067 (2006) (reporting similar trends).

146 Whitney R. Mauldin, Good Business/Bad Faith: Why the Insurance Industry Should Adopt a Good Faith Model, 44 TORT TRIAL \& INS. PraC. L.J. 151, 153 (2008).

147 See, e.g., Galanter \& Cahill, supra note 35, at 1386 (discussing the ways in which "informational disparities are accentuated" by confidential settlements); Lauren K. Robel, The Myth of Disposable Opinion: Unpublished Opinions and Government Litigants in the United States Courts of Appeals, 87 MicH. L. REv. 940, 955 (1989) (arguing that repeat players with first-hand knowledge of the content of unpublished opinions have informational advantages that better position them to prepare their cases). 
the information to cherry-pick past precedents that favor them, and to do so in ways that are not transparent to the informationally disadvantaged party. The databases used by these software programs for generating settlement valuations have been found to contain selective past-claims-payment histories. ${ }^{148}$ Notably, they have also been found to exclude as anomalies any jury verdicts or "high end" settlement values-but they nevertheless often include zero verdicts. ${ }^{149}$ As a result, critics have argued that these settlement databases allow insurance companies to negotiate systematically undervalued settlements. ${ }^{150}$

For these and other reasons, scholars have begun to call for the systematic compilation of settlement information into publicly available databases. ${ }^{151}$ Development and implementation of such databases may well help diminish the informational advantages that settlement in the shadow of settlement currently grants repeat players. These databases could also add transparency to a settlement market

148 But see Dawn R. Bonnett, The Use of Colossus $\AA$ To Measure the General Damages of a Personal Injury Claim Demonstrates Good Faith Claims Handling, 53 CLEV. ST. L. REV. 107, 131-32 (2006) (defending the use of Colossus to determine settlement values on the grounds that it provides for more consistent claims handling).

149 Robert D. Bennett, How To Deal with Colossus, in 2 Ass'N OF Trial LaWYers of Am., atla Annual Convention Reference Materials: Motor Vehicle Collision, Highway, and Premises LiAbility (2005); see also Dougherty v. AMCO Ins. Co., No. C 07-01140 MHP, 2008 WL 2563225, at *3 (N.D. Cal. June 23, 2008) ("The settlement range output by Colossus was based solely on pre-litigation settlements .... Neither jury verdicts, arbitration awards nor post-litigation settlements were reflected in the Colossus analysis of settlement value.").

150 See, e.g., David Dietz \& Darrell Preston, Home Insurers' Secret Tactics Cheat Fire Victims, Hike Profits, BLOOMBERG.COM, http://www.bloomberg.com/apps/news?pid=newsarchive\&sid=aIOpZROwhvNI (last visited Oct. 22, 2012) (describing settlement databases as part of a conscious plan by insurers to underpay claimants). As just one example, the Wall Street Journal presented the case of a seventeen-year-old who was severely injured in a car accident caused by a drunk driver. See Jerry Guidera, "Colossus" at the Accident Scene: Insurers Use a Software Program To Pay Out Claims for Injuries, but Lawsuits Claim It's Misused, WALL ST. J., Jan. 2, 2003, at C1. Colossus generated a payout of $\$ 31,588$; the girl's medical bills alone were over $\$ 18,000$. Id. She and her parents filed two separate suits against Allstate. Id. In the first suit, a Montana jury found for Sullivan in the amount of $\$ 105,000$; in the second suit, Allstate employees testified that the Colossus database did not include jury verdicts-the company settled four days into trial. Id.

151 For instance, Stephen Yeazell recently advocated for the creation of electronic databases whereby basic information about settlements-including, for instance, the amount of damages claimed, the place suit was filed, and the ultimate settlement amountwould be compiled and made accessible online. See generally Steven C. Yeazell, Transparency for Civil Settlements: NASDAQ for Lawsuits? (UCLA Sch. of Law, Law \& Economics Research Paper Series, Research Paper No. 08-15, 2011), available at http://ssrn.com/abstract=1161343. Similarly, Nora Engstrom has suggested that plaintiffs' attorneys who work on a contingency fee basis and seek damages in cases for personal injury or wrongful death should be subject to public disclosure requirements. Nora Freeman Engstrom, Sunlight and Settlement Mills, 86 N.Y.U. L. REv. 805, 866-68 (2011). 
that is still in many ways opaque ${ }^{152}$ and enable potential clients to make more informed attorney-selection decisions. ${ }^{153}$ But such correctives cannot cure the underlying problem that settlement outcomes themselves remain the product of distortive forces that the Federal Rules fail to mitigate, and in fact at times exacerbate. Thus, there is significant reason to pause before we further catalyze, and ultimately cement, the growing phenomenon of prior settlements serving as precedent ${ }^{154}$ for the formulation of expected-settlementvalue estimations.

Indeed, the proliferation of settlement databases -if implemented without sensitivity to the problems identified above and without the initiation of reforms along the lines this Article suggests-would simply bring about the pricing of substantive legal entitlements via the compilation of a set of distorted data points. Accordingly, the emerging problem of "precedent" in a world of settlement may be worse than critics of settlement have feared: Perhaps the modern concern about settlement is less that it fails to generate any public precedent and more that it is producing an abundance of bad precedents that fail to reflect in meaningful ways the dictates of the substantive law. In short, settlement may be moving increasingly out of the shadow of the law and into the shadow of itself, thereby over time molding "legal precedent," or what is generally thought of as "law," in its own image.

III

TOWARD THE FEDERAL RULES OF CIVIL SETTLEMENT

The shift to a world of settlement calls for fundamental procedural reform. As demonstrated in Part II, the current Rules fail to achieve a foundational objective of our civil justice system in a world of settlement: ensuring that case outcomes align with the merits of underlying disputes. In light of that goal, this Part takes steps toward the development of a new procedural regime for a world of settlement.

This Part begins by challenging three central assumptions of the current Rules, all of which fail to meaningfully align settlement

152 See Yeazell, supra note 151, at 2 ("[L]itigants and their lawyers price in the dark [and engage] in transactions for civil claims in a state of ignorance we think intolerable in other similarly important markets.").

153 See Engstrom, supra note 151, at 868-71 (citing analogous examples of disclosure use in medical markets and indicating that individuals in the legal market would make use of disclosed information).

154 See Baker \& Griffith, supra note 53, at 786 (stating that when lawyers talk about "expected trial-value," they actually mean "[t]his case is like other cases that we have settled"); Menkel-Meadow, supra note 30, at 2681 (pointing out that settlements are affected by past settlements). 
outcomes with the merits of underlying disputes. In so doing, this Part provides a framework for reform. Further, this Part addresses a number of reform proposals by procedure scholars and resituates them conceptually as challenges to these same three assumptions. Viewing these proposals through the lens of the mismatch between the current Rules and settlement offered in Part II, this Part argues that these proposals ought to be refined and expanded to address the specific distortions set forth in Part II, and to contribute to a more systematic redesign of the basic model and operation of the Federal Rules for a world of settlement. It then offers, as examples and for further consideration, new suggestions of the kinds of reforms that would break free from the core assumptions challenged here, and that are directed expressly toward aligning settlement outcomes with the merits of underlying disputes.

This Part concludes by presenting a new vision of the role of procedure to succeed that of the 1938 reformers. Instead of merely facilitating trial, pretrial procedures should be purposefully directed toward more meaningfully aligning settlement outcomes with the underlying merits. Pretrial procedure should be interdependent with substantive merits adjudication, not merely antecedent to it. In offering this new vision of our system of procedure, ${ }^{155}$ this Article lays the conceptual groundwork for the Federal Rules of Civil Settlement.

\section{A. Redesigning Procedure for a World of Settlement by Reconsidering Core Assumptions of the Federal Rules}

The shortcomings of the existing procedural rules, given the fundamental shift from a world of trials to a world of settlement, can be traced to three foundational assumptions underlying the Federal

155 To emphasize the need to redesign the Federal Rules for a world of settlement is not to take a position against the desirability of reforms that would move toward making trials once again commonplace. See Owen M. Fiss, The History of an Idea, 78 FoRDHAM L. REv. 1273, 1276 (2009) (arguing that the "strictures of public reason" imposed by adjudication-for instance, the confronting of grievances by a judge, the hearing of those grievances from affected parties, and the rendering of a decision based on principle-should be more robustly effectuated in a world of modern litigation). It is rather to acknowledge modern litigation realities and to adopt more modest ambitions for reform in the hope that such reform will be more likely. Although procedure cannot fix everything and no system of procedure will ever be perfect, the world of settlement demands better than our current system provides. To be sure, trial may not always live up to Fiss's ideals, and it is conceivable that the process of settlement can be imbued with some of the elements and values of trial. See Howard M. Erichson, Foreword: Reflections on the Adjudication-Settlement Divide, 78 FoRdHAM L. REV. 1117, 1127 (2009) ("The divide between adjudication and settlement has become increasingly blurry .... [E]ven where adjudication and settlement are neatly separable, the divide between them is not so stark as Fiss suggests in terms of the values they serve."). 
Rules of Civil Procedure. Those principles are first, that a regime of plenary discovery will generate case outcomes that accurately reflect the merits of underlying claims; second, that the role of pretrial procedures should be limited to the weeding out of meritless cases; and third, that the Federal Rules should apply generally to all types of claims, and across all types of cases.

This section examines each of these outmoded assumptions. It also argues that recent, isolated reform proposals can be better understood as challenges to these assumptions, and therefore as important starting points for addressing the deeper problem that the model of the Federal Rules of Civil Procedure is ill suited for a world of settlement. Given the problems discussed in Part II, this section suggests ways to refine and expand these proposals. It also sets forth additional reform proposals that break free of these foundational assumptions and are expressly oriented toward aligning settlement outcomes with the merits of underlying disputes.

\section{Rethinking the Assumption that Plenary Discovery Aligns Case Outcomes with the Merits}

The Federal Rules were premised on the notion that exhaustive information exchange through a regime of plenary discovery would facilitate the resolution of cases based upon the underlying merits. At one level, this premise seems uncontroversial: A system that generates more information would seem to lead to better results. And that logic may have been vindicated in the relatively straightforward cases typically brought in federal court in $1938 .{ }^{156}$ Some seventy years after the drafting of those rules, however, the work of the federal courts requires the resolution of far more complex claims arising under a plethora of new substantive statutes, often alleging wrongdoing on a national and even global scale. ${ }^{157}$ Many of the cases that exist today are of a complexity and scope largely unimagined at the time of the Federal Rules' enactment.

In the context of modern litigation, the notion that more discovery will always promote better merits-based resolution of claims needs to be revisited. As a general matter, current discovery rules are aimed almost exclusively at curing informational asymmetries, but they do so

156 See Resnik, supra note 27, at 512-13 (describing the assumption embedded in the Federal Rules that private litigants engaged in monetary disputes would have the resources to process a large volume of information).

157 See, e.g., Glover, supra note 23, at 1214 (citing variance between the United States and Europe both in the nature of particular procedural rules and in levels of reliance upon centralized regulation as factors inhibiting global-scale class actions). 
in a way that tends not to be sensitive to cost imposition, and they are not deployed in a manner that tries to reduce variance.

More specifically, the problem with this principle in a world of settlement has at least two dimensions. First, plenary discovery permits the imposition of high absolute costs, and the desire to avoid these costs drives settlement outcomes independent of the merits of the underlying claims. Although discovery costs are normally perceived as disadvantaging defendants, plenary discovery can often disadvantage plaintiffs by permitting defendants to conceal critical information through cost imposition. ${ }^{158}$

Second, in the context of complex, multi-faceted claims and issues, plenary discovery has the potential to permit cost imposition without producing, and indeed at the expense of, informational benefits on the substantive issues that would otherwise primarily drive settlement outcomes. Under the current Rules, cost imposition at the discovery stage is justified by the goal of bringing to light information on all claims for use at trial. The current Rules treat all claims and issues that satisfy the gate-keeping standard provided in the motion to dismiss as equal from the standpoint of discovery. ${ }^{159}$ However, in a world of settlement, certain substantive issues-for instance, those tied to a theory of liability that carries with it significant damages-predictably will exert disproportionate influence on parties' settlement decisions. Discovery on those issues would facilitate merits-based settlements while discovery on other, more tangential issues may simply impose additional absolute costs that add little information about the issues that matter most to settlement values and also may delay (or prevent) parties from unearthing facts relevant to those more critical claims. Thus, in a world of settlement, discovery promotes settlement outcomes that align with the merits to the extent that the cost imposition associated with that discovery is justified by the informational benefits of that discovery to the parties' settlement decisions, as opposed to the benefits that inure primarily to parties' trial preparations.

Recent discovery reform proposals, such as those suggesting more formalized mechanisms of targeted discovery, ${ }^{160}$ can be understood conceptually as raising a fundamental challenge to the viability of plenary discovery for purposes of aligning settlement outcomes with

\footnotetext{
158 See supra Part II.A.1.a.

159 FED. R. CIV. P. 26(b)(1).

160 The default of the Federal Rules is not to target discovery, but judges have authority to do so. See FED. R. CIV. P. 16(b)(3)(B)(ii), 16(c)(2)(F), 26(b)(2)(C), 26(c) (detailing methods by which judges may constrain the scope of discovery).
} 
the merits. For instance, scholars have suggested that issue-targeted discovery is needed to address asymmetrical cost imposition generated in the plenary discovery process. ${ }^{161}$ Specifically, it has been proposed that soon after the complaint and answer have been filed, the judge (with the parties' help) should identify those issues that will be contested at summary judgment, and then allow discovery to be performed only on them, leaving other potentially contestable issueslike damages-for later discovery if the initial issues survive summary judgment. ${ }^{162}$ And some district judges, especially in multi-district litigation cases, have employed such techniques in the exercise of their discretion, ${ }^{163}$ albeit not in uniform ways.

Targeted discovery along these lines could reduce the overall costs of discovery ${ }^{164}$ by eliminating discovery on issues that might be mooted by a successful motion for summary judgment. But these proposals should be refined so that they seek not only to eliminate potentially unnecessary costs but also to focus discovery efforts and their attendant costs more purposefully on issues most crucial to the parties' settlement decisions.

An example of a discovery reform that is sensitive to these additional considerations would take the following form: For cases with multiple claims, and potentially multi-faceted claims, a targeted discovery regime would be designed such that those claims capable of generating the most variance (for example, those involving statutory damages multipliers or civil penalties) are investigated and resolved first. This regime would thereby mitigate the effects of variance on settlement decisions by narrowing the range of outcomes through the development of merits-based information on those claims. Indeed, in certain circumstances, targeted discovery on damages issues ought to be conducted first, to the extent those issues exert the brunt of influence on parties' settlement decisions. Alternatively, as another

161 See Molot, Changes in the Legal Profession, supra note 100, at 1043-45 (arguing for targeted discovery as part of a package of reforms including strengthened summary judgment and fee-shifting provisions); see also Bone, Modeling Frivolous Suits, supra note 95, at 593-96 (arguing that judicial screening combined with targeted discovery is the best method of controlling frivolous litigation).

162 Molot, Changes in the Legal Profession, supra note 100, at 1043-44.

163 See, e.g., Klein v. King, 132 F.R.D. 525 (N.D. Cal. 1990) (entering a court order for targeted, phased, and sequenced discovery); MANUAL FOR COMPLEX LITIGATION (FouRTH) $\S$ 11.422 (2004) (endorsing targeted, phased, and sequenced discovery, but cautioning that the court must be sensitive to the risk that such discovery will be inefficient).

164 See generally JAMES S. KAKALIK ET AL., RAND INST. FOR CIVIL JUSTICE, JUST, SPEEDY, AND InEXPENSIVE: AN EVALUATION OF JUdiCIAL CASE MANAGEMENT UNDER THE Civil JUSTICE REFORM ACT 16 (1996) (finding that strict discovery cut-offs reduced time to disposition and litigation costs). 
example, dispositive (or near-dispositive) issues regarding key theories of liability would be investigated first, thus decreasing the overall amount of discovery needed to reach a settlement that reflects in substantial part the dictates of substantive law. ${ }^{165}$

A targeted discovery regime, properly designed for a world of settlement, would also address another shortcoming of the current system of plenary discovery-namely, the potential for defendants to exploit informational advantages and impose significant costs through voluminous production. Currently, plenary discovery invites full-scale strategic warfare. This model of mutually assured destruction ${ }^{166}$ enables a great deal of cost imposition and can do more to obscure than to illuminate facts ultimately bearing on the underlying merits of the claims. Therefore, a redesigned discovery regime would seek to reduce the volume of production generally as well as the search costs associated with voluminous production, while also being sensitive to the costs of production born by defendants. ${ }^{167}$ For example, Rule 34 ought possibly to be reformed to require defendants to organize production by type and origin of material produced, by subject matter, or by relationship to particular issues. Conceptually, these sorts of reforms, whatever the precise form they might ultimately take, would direct the informational advantages inuring to defendants toward illuminating merits-based issues. This would transform defendants' strategic incentives under the regime of plenary discovery from one of foisting immense search costs upon plaintiffs and obscuring the facts most salient to the underlying claims to ones of maintaining organized, easily searchable and retrievable files and of keeping manageable the task of organizing materials produced.

\section{Rethinking the Assumption that the Proper Role of Pretrial Adjudicative Mechanisms Is Limited to Screening Out Meritless Cases}

The presumption that the litigation process should (or at least

165 This Article leaves for another day needed consideration of whether doctrines regarding evidentiary privileges and work product doctrines, in current form, impede the exchange of information in a manner that would help generate merits-based settlements.

166 See generally John K. Setear, The Barrister and the Bomb: The Dynamics of Cooperation, Nuclear Deterrence, and Discovery Abuse, 69 B.U. L. REv. 569 (1989) (applying the game theory principles of nuclear deterrence to parties' decisions whether to engage in abusive discovery practices).

167 As a preliminary matter, the Rules Advisory Committee should consider the extent to which it would help, in some instances, to have special masters with expertise in particularized substantive areas guide issue-targeted discovery. This could help informationally disadvantaged claimants craft narrower requests, either in the first instance, or after a limited period of initial discovery on a given issue. 
does) culminate in the adjudication of cases on the merits at trial, and that pretrial adjudication should be limited to screening out meritless cases, undergirds the 1938 regime of notice pleading, liberal discovery, and summary judgment. As discussed above, under current rules, the resolution of factual disputes and the application of substantive law to the evidence occur at trial, and pretrial adjudicative mechanisms employ standards that provide little guidance about the factual strength of claims. ${ }^{168}$

This assumption too is unworkable in a world of settlement for two fundamental reasons. First, the minimal merits screening currently provided by pretrial procedures is inadequate to mitigate the effects of the external forces detailed in Part II that can cause settlements to deviate from the dictates of the substantive law. By design, screening mechanisms simply exclude claims from the litigation system altogether. They do little to reduce the level of variance generated by surviving claims, mitigate the costs associated with discovery on surviving claims, or eliminate non-case-dispositive legal uncertainties that bear on settlement decisions.

Second, current pretrial rules are inadequate to provide the kind of robust information about the substantive merits that can narrow parties' disparate evaluations of the value of their claims and guide settlement negotiations toward merits-reflective case resolution. In a world dominated by settlement, pretrial rules can no longer be viewed primarily as way-stations on the road to what is now a virtually nonexistent endpoint. Instead, if parties' settlement decisions are to reflect in meaningful ways the merits of the underlying claims, pretrial rules must be harnessed (or created, where necessary) to provide parties with more meaningful merits-based guidance for settlement.

To address both of these problems, pretrial procedures should be reformed to enable courts to provide more meaningful merits-based guidance for settlement decisions. Moreover, where appropriate, courts' pretrial merits-based guidance should have operational consequences for parties' access to additional procedural mechanisms that can distort settlement outcomes. This section illustrates these principles by setting forth for further consideration examples of reforms at the pleading stage and at subsequent stages of the litigation.

a. Harnessing Pleading-Stage Procedural Mechanisms To

Provide More Robust Merits-Based Guidance

The fundamental precept behind notice pleading, introduced in

168 See supra Part II.A.2. 
1938, is simply to provide defendants with notice of claims brought against them. Notice pleading was not designed to provide an opportunity for the evaluation of the strengths or weaknesses of claims. Over time, however, critics of notice pleading expressed concern that this regime allowed meritless cases to proceed to discovery and engender settlements that were based largely, if not exclusively, on distortive effects such as discovery costs and high levels of variance in outcomes. In an attempt to ameliorate these concerns, in 2007 the Supreme Court introduced a more rigorous pleading-stage screen: the plausibility standard. ${ }^{169}$

While the Supreme Court's plausibility standard was a reaction to the problem of cost imposition as a distortive force on settlement outcomes, the standard is seen to be inadequate from the standpoint of this Article's focus on better aligning settlement outcomes with the merits of underlying claims. First, the new plausibility standard is overbroad and may well screen out potentially meritorious cases, because no mechanism exists at the pleading stage for recalibrating informational imbalances that may favor defendants at that stage of litigation. Second, the new standard does nothing to mitigate the potential for claims that survive the motion to dismiss stage to generate the very distortions about which the Court was concerned when it articulated a new pleading standard-namely, the distortions that stem from the costs, and threat of costs, of the open-ended discovery process. This concern about discovery-related distortions creates a vicious feedback loop: It may well exacerbate the first problem with the plausibility pleading standard-that is, it can be applied too broadly to overscreen even meritorious claims-because the concern puts pressure on courts to evaluate the strength of claims regardless of whether plaintiffs could have produced factual information sufficient to support a plausibility analysis at such an early juncture in the litigation process.

Instead, the plausibility pleading standard, as part of a properly designed pleading stage of litigation, could be harnessed as a mechanism for guiding settlement decisions. To do so, however, the

169 See Bell Atl. Corp. v. Twombly, 550 U.S. 544 (2007); see also Ashcroft v. Iqbal, 559 U.S. 662 (2009). The Court's decisions in these cases issue yet another challenge to the evereroding assumption that, under the Federal Rules, there is a bright-line separation between questions of fact and law. See, e.g., Epstein, supra note 99, at 72 (describing Twombly as the culmination of a trend in lower courts towards disapproval of a rigid division between fact and law). This challenge was embedded in the Iqbal opinion, wherein the Court noted that the plaintiff's complaint cited information available to the public that actually disproved plaintiff's claims. See Iqbal, 556 U.S. at 681-82 (considering plaintiff's claims of discrimination and offering an "obvious alternative explanation" for the conduct described in the complaint (quoting Twombly, 550 U.S. at 567)). 
pleading stage at which this plausibility standard operates should be reformed. Fundamentally, the pleading stage should be conceptualized not as a binary switch for screening out claims, but rather as a more flexible mechanism for providing merits-based guidance to parties early in the litigation process. Accordingly, the pleading Rules should be supplemented with mechanisms that would enable courts to perform this merits-based analysis in a factually informed way.

Again, recent, isolated procedural reform proposals are better situated as part of the broader enterprise of changing pleading-stage procedures to foster merits-based guidance for settlements. One set of proposals suggests that Rule 12 be supplemented with an analog to Rule 56(d) (formerly Rule 56(f)), so as to permit a party facing a motion to dismiss to request discovery in relation to a particular claim or set of claims. ${ }^{170}$ Under this new mechanism, plaintiffs would be required to show that public information available to them is "insufficient," without discovery, to satisfy the plausibility pleading standard. ${ }^{171}$ Another proposal seeks to harness the strategic incentives of the parties themselves in producing the relevant information for a plausibility analysis. Presented specifically with regard to the scienter requirement in securities litigation, Professor Geoffrey Miller proposes that a plaintiff be given the option to file an objection to the grant of a motion to dismiss for failure to state a plausible ground for relief, at which time the court's order would be vacated and litigation would proceed to discovery. ${ }^{172}$ However, the defendant could obtain reimbursement for post-dismissal attorney's fees if summary judgment is later granted. ${ }^{173}$

As a preliminary matter, these two proposals reflect an understanding of the changed informational architecture of modern litigation at the pleading stage. In particular, these proposals can be understood conceptually as challenging the supposition, embedded in the 1938 regime of notice pleading, that defendants will tend to control key information bearing on the merits of the dispute at the pleading

170 See Fed. R. Civ. P. 12, 56(d).

171 See Colin T. Reardon, Note, Pleading in the Information Age, 85 N.Y.U. L. REv. 2170, 2206 (2010) (describing such a reform); see also Scott Dodson, New Pleading, New Discovery, 109 MiCH. L. REv. 53, 79 (2010) (proposing mechanisms of pleading-stage discovery analogous to the former Rule 56(f)). A related, but far more limited proposal is that plaintiffs should be fined or subject to a stricter set of penalties under the existing Rule 11 for abject failure to perform a pre-filing investigation of their claims. Bone, Regulation of Court Access, supra note 6, at 931-32 \& n.243.

172 Geoffrey P. Miller, A Modest Proposal for Securities Fraud Pleading After Tellabs 17-18 (New York University Law and Economics Working Papers, Paper No. 265, 2011), available at http://lsr.nellco.org/nyu_lewp/265.

173 Id. 
stage. This assumption is less accurate today. Indeed, scholars have begun to trace a historical shift in informational asymmetries, ${ }^{174}$ finding that technological and regulatory changes have made relevant factual information more available and have made informal methods of investigation simpler and less expensive. ${ }^{175}$ In some subsets of cases, then, plaintiffs may be able to provide sufficient factual support for claims without discovery, or at least enough to survive a motion to dismiss even under a plausibility pleading standard. ${ }^{176}$

Moreover, these proposals are promising steps toward enabling courts to provide, and parties to obtain, meaningful merits-based information at the pleading stage. Furthermore, some mechanism of preliminary discovery at the pleading stage could reduce the extent to which defendants can exploit informational imbalances in motions to dismiss. ${ }^{177}$ Viewed within the framework of this Article, however, to

174 See Reardon, supra note 171, at 2171 (describing developments since 1938 that have eased informational asymmetries, including lower search costs due to the internet, the related ease of spreading and difficulty of containing "damning information," and the emergence of laws and regulations "forcing or facilitating the disclosure of once-private information").

175 Along these lines, Richard Epstein argues that the Court's decision in Twombly can be better defended with reasoning about changes in informational architecture. See Epstein, supra note 99, at 81-82 (viewing Twombly as articulating a preference against discovery when the complaint relies upon public information). Reasonable minds can and do differ as to whether the information available to the public about an alleged antitrust conspiracy in Twombly (or about antitrust conspiracies more generally) is sufficient for plaintiffs to satisfy the plausibility standard. See, e.g., Bone, Regulation of Court Access, supra note 6, at 919-20 (noting that in Twombly, the defendants had a great deal of information relevant to potential liability, while the plaintiffs had very little).

176 The internet is of course a big part of this story. Websites provide claimants and attorneys with access to information about potential defendants and alleged wrongdoing; indeed, some of these sites are government-sponsored and specifically designed to do so. See, e.g., Filings \& Forms, SEC.Gov, http://www.sec.gov/edgar.shtml (last updated Feb. 21, 2012) (providing a public interface for viewing corporate SEC filings); RECALLS.gov, http://www.recalls.gov (last visited Oct. 22, 2012) (collecting product recall information from several agencies in a central database). Internet-based background-checks permit users to locate public records of companies or individuals. See, e.g., Pricing, KNowX, http://www.knowx.com/statmnts/priceinfo.jsp (last visited Oct. 22, 2012). Even social networking sites provide key factual information about relevant claims. See Sean Wajert, Informal Discovery Leads to Dismissal in MDL, MASS TORT DEF. (Feb. 2, 2010), http://www.masstortdefense.com/2010/02/articles/informal-discovery-leads-to-

dismissal-in-mdl/ (discussing a case in which "plaintiff's claims of severe disability were refuted by [Facebook] photos... that appeared to show plaintiff competing in strenuous high-speed powerboat races"). Furthermore, a number of laws now mandate or facilitate the production of information about investigations and occurrences of wrongdoing. See generally Reardon, supra note 171, at 2191-99 (cataloguing laws regulating information disclosure).

177 As another variant of this idea, FED. R. CIV. P. 27 could be revised to permit pre-suit discovery not just for purposes of perpetuating testimony, but also for preliminary investigation of claim viability, proper parties to sue, and the like. Such arrangements have begun to emerge in a few states, most prominently Texas. See TEX. R. CIV. P. 202. 
better harness pleading-stage procedures and to provide parties with merits-based guidance for settlement evaluations, such reforms require further refinement and additional reforms may be needed.

To begin, a Rule 56(f)-equivalent mechanism should be refined to provide judges with more concrete guidance for determining whether pleading-stage discovery is warranted than is afforded by a highly discretionary "insufficiency" standard. Of course, the formulation of such guidance would likely require empirical studies, conducted perhaps by the Rules Advisory Committee (through the FJC) to determine the extent to which certain types of cases are characterized by substantial amounts of information available pre-discovery. Moreover, empirical research is needed to help the Advisory Committee determine, and then articulate in the relevant new rule, what it means for information to be "available." At the very least, to be "available," information must be capable of being cost-effectively obtained and presented in a way easily understood by potential claimants. ${ }^{178}$

Research along these lines would help the Advisory Committee provide judges with a concrete list of factors for determining whether pleading-stage discovery is warranted, thereby cabining unfettered discretion and better assuring that such analysis is not thwarted by judges' own informational disadvantages. As examples, the committee could direct judges toward a presumption in favor of permitting limited pleading-stage discovery in (1) cases involving claims that require a showing of defendant's mental state or discriminatory animus; ${ }^{179}$ (2) cases involving defendants who are otherwise not subject to significant regulatory disclosure requirements generally; ${ }^{180}$ (3) cases involving plaintiffs who were denied requests for information under, for instance, the Freedom of Information Act (FOIA), ${ }^{181}$ or, relatedly, have waited out to no avail the statutory response deadline for agencies provided in FOIA; ${ }^{182}$ (4) cases in which publicly available

178 See, e.g., Glover, supra note 23, at 1182 (illustrating the advantage public regulators have in compiling and analyzing information in the context of a broad landscape of complex data, such as the consumer financial market); see generally Samuel Issacharoff, Disclosure, Agents, and Consumer Protection, 167 J. Institutional \& Theoretical Econ. 56 (2011) (discussing the need for market agents who can present information to consumers in an understandable way that might generate operational choices).

179 See, e.g., Dodson, supra note 171, at 67 (discussing employment discrimination plaintiffs' lack of access to information).

180 See Reardon, supra note 171, at 2203 (warning that "plaintiffs suing firms in lightly regulated industries" are likely to face the greatest amount of informational asymmetry given the lack of regulatory disclosure requirements).

1815 U.S.C. $§ 552$ (2006).

182 See Pete Weitzel, Sunshine in Gov't Initiative, Fewer Requests, Fewer Responses, 
information about the activities alleged is contained in the informational disseminations of defendants themselves, who have a strategic incentive ex ante to present selectively any information about their nature, activities, or operations in public fora; or (5) cases in which plaintiffs do not have access to relevant technological resources for obtaining claim-related factual information. These characteristics would tend to indicate that information relevant to wrongdoing is unlikely "publicly available."

Conversely, factors suggesting that information relevant to wrongdoing is "publicly available" to plaintiffs for purposes of plausibility pleading include: (1) whether claims are based upon allegations of activities that are subject to regulatory disclosure requirements; ${ }^{183}$ (2) whether a case involves claims whose basic factual predicates could be established through online research of publicly available, independently operated sites; ${ }^{184}$ (3) whether plaintiffs could (but did not) make a request for information under, say, FOIA; ${ }^{185}$ or (4) whether plaintiffs in a given case have access to relevant technological resources for obtaining claim-related factual information. Analysis of these sorts of factors would of course require the judge to consider the particular characteristics of a given case in applying them (though, of course, not all of these factors would arise in every case), especially given the risk that parties would invoke boilerplate language in motions either seeking to obtain or seeking to prevent pleading-stage discovery. However, such factors would provide for a more bounded and predictable exercise of discretion than is typically found in current rules.

More fundamentally, a new procedural rule for limited pleadingstage discovery should not carry with it a rebuttable presumption that plaintiffs in all cases can obtain information sufficient to survive a plausibility analysis without discovery. This point is equally applicable to the potential introduction of a Rule 56(f)-equivalent mechanism or a

\footnotetext{
MORE DENIALS 2 (2009), available at

http://www.sunshineingovernment.org/stats/highlights.pdf (finding that agencies miss the statutory response deadline in a majority of cases).

183 For instance, the recently enacted Dodd-Frank Wall Street Reform and Consumer Protection Act contains a number of provisions that require disclosures by regulated entities. See, e.g., Dodd-Frank Wall Street Reform and Consumer Protection Act, Pub. L. No. 111-203, §115, 124 Stat. 1376, 1403-06 (2010) (to be codified at 12 U.S.C. § 5325) (detailing one form of enhanced public disclosure). Of course, the efficacy of such disclosure provisions will require research of the Act's practical effects in the coming years.

184 For a discussion of the sorts of elements that can be supported factually through online research of publicly available websites, see Reardon, supra note 171, at 2188-90.

185 See id. at 2204 ("FOIA disclosures can likewise reveal little-known government policies and provide detail on their operation.").
} 
conditional motion to dismiss. Regarding the former, a showing of need for pleading-stage discovery under the currently proposed Rule 56(f)-equivalent mechanism will impose additional costs upon plaintiffs-costs which may well be justified in some subset of cases, but might be entirely wasteful and potentially distortive of settlements in cases characterized by an informational monopoly on the part of defendants. ${ }^{186}$

Requiring a showing of need for discovery in all cases creates a presumption insensitive to such distinctions. And for cases in which defendants possess informational advantages relative to the plaintiff and to the judge, this sort of rebuttable presumption would more readily enable defendants to exploit informational asymmetries through complex and selectively informed Twombly motions and oppositions to plaintiffs' required showing under the new Rule 56(f)derived mechanism. That strategic exploitation could in turn drive potentially meritorious claims out of the system or force down early settlement values for reasons unrelated to the underlying merits. A rebuttable presumption in the other direction, however, harnesses the strategic incentives of the party almost assuredly in possession of information relevant to claimants' allegations-the defendant-to make the court and plaintiffs aware of the sources of public information.

Similarly, a conditional motion to dismiss may work well when plaintiffs can reasonably be expected, pre-discovery, to have meaningful access to relevant facts; however, for cases characterized by significant informational imbalances-for example, cases involving employment discrimination ${ }^{187}$ - the potential fee-shift may simply chill claiming. ${ }^{188}$ It is true, as Miller notes, that plaintiffs' option to drop their case prior to summary judgment to avoid fee-shifting may mitigate such a concern, ${ }^{189}$ at least in some cases. ${ }^{190}$ But that just leaves

186 For example, informational asymmetries may occur in cases involving wrongdoing that occurred in private and cases involving questions about a defendant's mental state, discriminatory intent, or small or closely-held companies. Id. at 2203.

187 Chilling effects are particularly problematic to the extent that they are pronounced in areas of the law where Congress relies heavily (or exclusively) on private parties for the policing of wrongdoing. See Glover, supra note 23, at 1148-49 (discussing the shifting reliance by Congress on private party litigation for the regulation of employment discrimination).

188 It is not entirely clear whether a fee-shifting mechanism could be introduced by the Rules Advisory Committee under its limited rulemaking power or if Congress must introduce such a regime. This Article does not take up that debate.

189 Miller, supra note 172, at 19.

190 The option to drop one's case may not sufficiently mitigate this concern for cases in which claimants are at a significant informational and pecuniary disadvantage. 
in place the distortive forces associated with the discovery process. ${ }^{191}$ By postponing a factually informed plausibility analysis until the statistically unlikely summary judgment stage, without additional mechanisms in the discovery process to mitigate either the exploitation of informational asymmetries or the imposition of substantial discovery costs, the conditional motion to dismiss may well leave intact the same sorts of distortive effects on settlement outcomes present in the current regime. ${ }^{192}$

One way to address these problems would be to provide for a Rule 56(f)-equivalent mechanism for plausibility pleading-rebuttable presumption and all-only when the judge determines, guided by specific factors articulated by the Advisory Committee in the new rule itself, that plaintiffs can reasonably be expected to access relevant information in the public domain. ${ }^{193}$ Such a regime would be supplemented, at least in close cases, with a conditional grant of a motion to dismiss with a cost-shifting regime, as well as additional mechanisms designed to provide merits-based guidance throughout the discovery process to mitigate the distortive effects of unfettered discovery. ${ }^{194}$

Another way to address these problems would be to use a plausibility pleading standard for all claims (which holds promise, appropriately modified, not only to provide parties with more robust merits-related information earlier in the litigation), but to incorporate an additional rebuttable presumption in favor of limited discovery at the pleading stage. Such a reform would harness the strategic incentives of the defendant to produce relevant, publicly available information in opposing pleading-stage discovery, at least in the subset of cases or claims the Rules Advisory Committee determines likely

\footnotetext{
191 See generally supra Part II.A.2.
}

192 Even if, in light of a fee-shifting threat, parties more robustly analyzed the likelihood of success at summary judgment, such analysis would likely not reliably mitigate these effects, particularly given attorneys' tendencies to overestimate their likelihood of success on the merits. See Goodman-Delahunty et al., supra note 90, at 137, 140-41 (presenting empirical data suggesting that lawyers are prone to overconfidence about their cases).

193 There is precedent for limited pleading-stage discovery: Judges often allow targeted discovery before deciding a motion to dismiss for lack of subject matter or personal jurisdiction. It is unclear whether judges have authority to do so under the Federal Rules when deciding a motion to dismiss for failure to state a claim when faced with heightened pleading standards. Compare In re Graphics Processing Units Antitrust Litig., 527 F. Supp. 2d 1011, 1032-33 (N.D. Cal. 2007) (noting that narrowly-tailored discovery might be permitted before the plaintiff filed an amended complaint, provided that such discovery is deemed necessary), with In re Flash Memory Antitrust Litig., No. C 07-0086 SBA, 2008 U.S. Dist. LEXIS 62278, at*29 (N.D. Cal. Jan. 4, 2008) (stating that there is no authorization in the Federal Rules for pre-dismissal discovery).

194 See infra Part III.A.2.b. 
warrant such discovery.

As another alternative, particularly for cases in which the rebuttable presumption regarding pleading-stage discovery appropriately favors such discovery, pleading would be a two-stage process. Under this regime, for the subset of cases for which the Advisory Committee has determined that public information regarding wrongdoing is unlikely to be available to would-be plaintiffs, an initial evaluation of the complaint would be made under the "no set of facts" standard set forth in Conley v. Gibson. ${ }^{195}$ After this, limited discovery would be conducted in preparation for a more robust evaluation of whether plaintiffs have stated a "plausible" claim for relief. The goal of such a reform, like the other possible reforms discussed in this section, would be to harness pleading-stage procedures to enable courts to introduce meaningful merits-based information earlier in the litigation process.

b. Creating Post-Pleading-Stage Mechanisms that Provide Meaningful Merits-Based Guidance

The presumption that meaningful merits-based analysis should occur only after the conclusion of the discovery process also fails in a world of settlement, in two key respects. First, parties tend to make settlement evaluations after the motion to dismiss and during the discovery process; therefore, if analysis of the merits of claims by someone other than the parties themselves is to influence parties' settlement decisions, mechanisms for such analysis are needed during that stage of the litigation. Second, the current rules lack mechanisms that would enable courts to manage the impact of external forces on settlement outcomes by tying merits evaluations to access to discovery procedures.

Once more, recent reform proposals are better resituated as challenging the continued viability of a foundational assumption of the Federal Rules: the assumption that robust merits analysis should occur at the end of the discovery process. For example, Geoffrey Miller has recently suggested the introduction of a "preliminary judgment" mechanism whereby parties could obtain a nonbinding assessment of the merits of the dispute. ${ }^{196}$ Through a preliminary judgment, the judge would evaluate claims or defenses based on information provided by

195355 U.S. 41, 45-46 (1957). Such a regime implicitly rejects the new-and equally incorrect-foundational premise injected into the Federal Rules by Twombly and Iqbal that, across the entire swath of cases brought in federal court, plaintiffs have access to public information sufficient to support their claims under the heightened standard.

196 Geoffrey P. Miller, Preliminary Judgments, 2010 U. ILL. L. REV. 165, 165 (2010). 
the parties, and the judgment would be available at any time upon a party's request, presuming the court concludes that the materials presented are sufficient to make such a provisional assessment. ${ }^{197}$ Once issued, the judgment would "convert into a final judgment after the expiration of a reasonable period of time," but before the expiration of that time period, the party against whom the judgment is entered could object, with or without explanation, thus causing the order to be vacated. ${ }^{198}$ This early-issuing, merits-based assessment would, Miller argues, encourage settlement by better enabling the convergence of parties' respective expected-value calculations; mitigate parties' tendencies to hold fast to original anchors about expected values; trigger serious settlement negotiations that are more focused on the issues of the case; help counter nuisance suits; and increase transparency, presuming such judgments would be publicly available. ${ }^{199}$

Miller's proposal offers a valuable corrective to the outdated presumption that robust merits-based adjudication will enter the lawsuit at the end of the litigation process. And such a reform could dovetail with the new pleading and discovery mechanisms proposed above. However, this proposal does not go far enough.

Although a preliminary judgment mechanism would help address the current pretrial procedures' failure to provide useful information about the merits of the dispute with any real rigor, ${ }^{200}$ the proposal does not fully address the other key reason that parties need such meritsbased analysis: the distortions of settlement outcomes generated by the access to and use of discovery procedures. To mitigate these distortions and better align settlement outcomes with the merits of disputes, access to and use of pretrial procedures must be tied to merits-based analysis. Put simply, a preliminary judgment mechanism must generate operational consequences for the parties' use of pretrial procedures. This is the basic intuition behind a recent doctrinal shift in the context of Rule 23, lauded by some procedure scholars ${ }^{201}$ and decried by others, ${ }^{202}$ toward greater merits scrutiny at the class

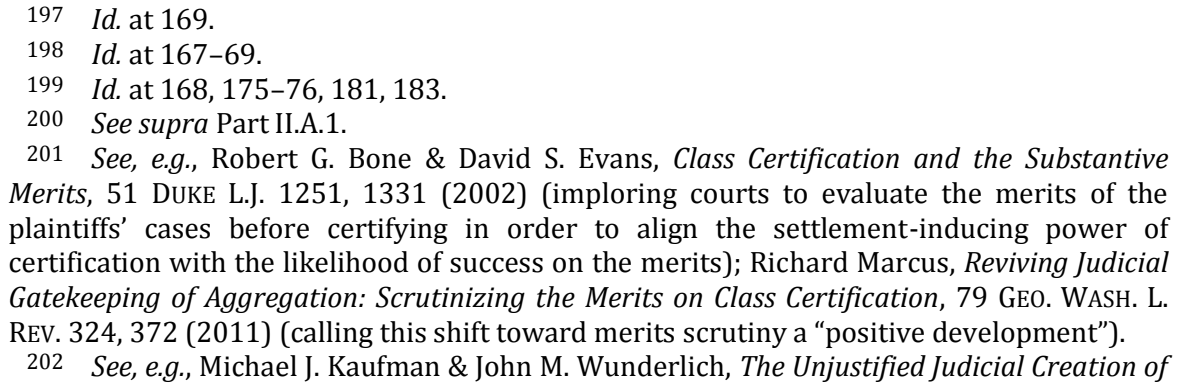
Merits, 51 DUKE L.J. 1251, 1331 (2002) (imploring courts to evaluate the merits of the plaintiffs' cases before certifying in order to align the settlement-inducing power of certification with the likelihood of success on the merits); Richard Marcus, Reviving Judicial Gatekeeping of Aggregation: Scrutinizing the Merits on Class Certification, 79 GEO. WASH. L. REV. 324, 372 (2011) (calling this shift toward merits scrutiny a "positive development").

202 See, e.g., Michael J. Kaufman \& John M. Wunderlich, The Unjustified Judicial Creation of 
certification stage. ${ }^{203}$ This shift has been motivated by the recognition that allocation of a procedural entitlement-the ability to proceed as a class under Rule 23-generates a great deal of variance, and that access to this variance should be granted in correlation with the dictates of governing law in a given dispute.

Along these lines, if a preliminary judgment indicates that a party's likelihood of success on a particular issue is low, but carries no consequences for the allocation of procedural entitlements-for instance, if that judgment does nothing to change a party's ability to impose significant discovery costs - then the ability of costs to distort settlement outcomes will remain largely unmitigated and will perhaps dwarf the impact of a preliminary judgment on parties' settlement valuations. Conversely, if a preliminary judgment indicates that a party is likely to succeed on a particular issue, but does nothing, for instance, to adjust the opposing party's ability to foist substantial discovery costs through voluminous production, noticing of multiple depositions, or discovery requests on collateral matters, then the preliminary judgment again will have failed to mitigate the effect of that cost imposition on the ultimate settlement. Indeed, without a connection to the dispensation of procedural entitlements, the valuable merits-based data generated by these preliminary judgments risk being outweighed by the ongoing effects of procedural distortions for purposes of settlement valuations. And, as a result, judges would likely have little incentive to invest the time and effort required to provide an early assessment of the strengths and weaknesses of the claim.

A modified proposal, therefore, could take the following form: A preliminary judgment that is issued after discovery on a discrete issue under a targeted discovery regime should directly inform the allocation of additional discovery entitlements. After the issuance of the preliminary judgment, the judge could permit additional discovery

Class Certification Merits Trials in Securities Fraud Actions, 43 U. Mich. J.L. REFoRm 323, 323 (2010) (arguing against the practice of merits-based certification because of inconsistencies with legal precedent, infringement upon the right to a jury, and unfounded fear of postcertification discovery costs); Steig D. Olson, "Chipping Away": The Misguided Trend Toward Resolving Merits Disputes as Part of the Class Certification Calculus, 43 U.S.F. L. REv. 935, 939 (2009) (contending that this shift "make[s] class certification a more onerous and less efficient process").

203 See In re Hydrogen Peroxide Antitrust Litig., 552 F.3d 305, 316 (3d Cir. 2008) ("An overlap between a class certification requirement and the merits of a claim is no reason to decline to resolve relevant disputes when necessary to determine whether a class certification requirement is met."); In re Initial Pub. Offering Sec. Litig., 471 F.3d 24, 27 (2d Cir. 2006) (holding "that the fact that a Rule 23 requirement might overlap with an issue on the merits does not avoid the court's obligation to make a ruling [at the pretrial stage] as to whether the requirement is met"). 
on a given issue beyond what was already provided by the targeted discovery phase; however, such additional discovery could carry a cost-shifting mechanism-either against the requesting party (if some higher showing of merits related to the relevant claim is not made after further discovery), or against the producing party (if additional discovery reveals that the producing party had withheld key materials or information).

For illustration, consider the following hypotheticals. First, assume that a claimant's ultimate success on the merits turns largely on one element of a particular claim. Assume further that the claimant has survived the defendant's motion to dismiss. Also assume that plenary discovery on all elements of the relevant claim would be costly and that those costs would affect settlement values. Discovery would be initially limited to matters related to the concrete allegations about the crucial element, after which a preliminary judgment would be made. Further discovery would not be permitted unless, on preliminary judgment, some heightened showing of entitlement to relief in line with those allegations or very closely related allegations is made. Or, if no such showing is made at that point, the parties are made subject to cost-shifting if either no additional showing is made (by claimant) or further production reveals that the responding party (usually the defendant) had been withholding information.

Now assume, as a second hypothetical, that plaintiffs file a complaint alleging three claims for relief, all of which survive the motion to dismiss stage, either as it currently exists, or under some modified discovery regime at the pleading stage. Assume again that discovery on all three claims would be costly and that those costs would influence settlement values. Also assume, however, that one of the three claims carries with it the potential entitlement to substantial damages relative to the other two claims because, for instance, one of the claims arises under a statute containing treble damages or statutory penalties. Here, pinpoint discovery would be conducted on the high-damages claim alone, after which the judge would issue a preliminary, nonbinding evaluation of the strengths of that claim. ${ }^{204}$

204 Particularly in cases characterized by significant informational imbalances, the timing for the issuance of a preliminary judgment might also prove critical. To the extent the judge is at an informational disadvantage about the facts of the dispute (as can often be the case), tying the issuance of a preliminary judgment to a party's request creates a strategic incentive for the informationally advantaged party to obscure damaging facts. That party, perhaps through production to the court of either voluminous or selectively revealed information, could create the appearance that "sufficient" information exists for the rendering of the preliminary judgment. Therefore, the timing for the issuance of a preliminary judgment is more appropriately tied to the end of a discrete discovery phase, which will better ensure that presentation of relevant materials to the judge is provided 
Such an evaluation would not only help align settlement calculations with the underlying merits and damages entitlements by providing merits-based information and reducing the level of variance in the case, but, crucially, it would also dictate the extent to which further discovery would be permitted. For instance, if the judge determines that the claimants' likelihood of success on that claim is low, further discovery on that claim could be permitted, but subject to a costshifting mechanism should plaintiff fail to make a further showing of the claim's merit (or against defendants if it is revealed that information has been withheld). Or, if the judge determines that the plaintiffs' likelihood of success on the merits of a claim is high, the judge should supervise discovery with a view toward ensuring that plaintiffs have access to additional discovery for purposes of proving that claim. In either case, such judgments would impose limitations on discovery on any additional issues that exert relatively little influence on settlement decisions. These procedural consequences would help further illuminate information most relevant to settlement and reduce the potentially distortive effect of cost imposition on ultimate settlement values.

\section{Rethinking the Assumption that Procedural Rules Should Apply Uniformly and Transsubstantively to All Cases}

The Federal Rules were designed to apply uniformly, meaning that they apply across all federal jurisdictions and to all cases brought in those jurisdictions. ${ }^{205}$ They were also designed to apply transsubstantively, meaning that they apply to all cases, regardless of the substance of underlying claims. ${ }^{206} \mathrm{I}$ am certainly not the first to challenge the continued viability of these foundational principles, as a general matter.207 To begin, scholars have argued that the

through the lens of both parties.

205 Rule 1 provides that "[t]hese rules govern the procedure in all civil actions and proceedings in the United States district courts," with those limited classes of cases enumerated in Rule 81 providing the only exceptions. FED. R. CIV. P. 1; FED. R. CIV. P. 81. These foundational principles are generally understood to constrain the rulemaking process under the Rules Enabling Act. See Stephen B. Burbank, Pleading and the Dilemmas of “General Rules," 2009 WIS. L. REv. 535, 541-42 [hereinafter Burbank, Pleading]. Professor Burbank has argued, however, that the Rules Enabling Act does not necessarily command such an interpretation. See Burbank, The Transformation of American Civil Procedure: The Example of Rule 11, 137 U. PA. L. REv. 1925, 1934-35 (1988) (questioning whether the legislative history of the 1934 Rules Enabling Act requires transsubstantive rules).

206 See, e.g., David Marcus, The Past, Present, and Future of Trans-substantivity in Federal Civil Procedure, 59 DePaul L. REv. 371, 376 (2010) (setting forth the meaning of transsubstantivity).

207 See, e.g., Stephen B. Burbank, Of Rules and Discretion: The Supreme Court, Federal Rules and Common Law, 63 NotRe DAme L. Rev. 693, 716-17 (1988) [hereinafter Burbank, of 
transsubstantive and uniform nature of the Federal Rules is actually a bit fictitious, given judges' discretion in the application of those rules to various cases ${ }^{208}$ (discretion that has been more formally embodied in changes to the Federal Rules over time). ${ }^{209}$ Further, as the range of complexity in federal cases has grown, lower federal courts have struggled against the constraints of these principles ${ }^{210}$ and Congress has enacted tailored rules for certain doctrinal areas. ${ }^{211}$ In addition, some scholars have challenged these principles directly by proposing substance-specific procedural reforms, ${ }^{212}$ while others have challenged them more indirectly, through theoretical critiques of unbounded judicial discretion. ${ }^{213}$ That said, scholars acknowledge that these principles still maintain a strong hold on rulemaking. ${ }^{214}$

Viewing the principles of transsubstantivity and uniformity through the lens of this Article provides an additional perspectivenamely, that they can impede achievement of aligning settlement outcomes with the merits of underlying disputes. These principles tend to be insensitive to the fact that different subsets of cases, or subsets of

Rules and Discretion] (basing his argument that strict adherence to procedural transsubstantivity is untenable on the fact that specialized procedural rules and approaches already exist, such as in the case of RICO lawsuits, civil rights litigation, and complex litigation); Stephen N. Subrin, Federal Rules, Local Rules, and State Rules: Uniformity, Divergence, and Emerging Procedural Patterns, 137 U. PA. L. REV. 1999, 2025 (1989) (noting the emergence of "procedures for particular types of cases").

208 See, e.g., Stephen B. Burbank \& Linda J. Silberman, Civil Procedure Reform in Comparative Context: The United States of America, 45 AM. J. ComP. L. 675, 699-700 (1997) (describing transsubstantive procedure as a myth, given the amount of discretion trial judges have); Paul D. Carrington, Politics and Civil Procedure Rulemaking: Reflections on Experience, 60 DuKE L. J. 597, 621-22, 644 (2010) (citing jury impaneling and Rule 11 sanctions in illustrating the breadth of procedural discretion granted to judges). But see Marcus, supra note 206, at 378 (arguing that this claim about the relationship between judicial discretion and transsubstantivity sweeps too broadly).

209 See, e.g., FED. R. CIV. P. 16 (laying out various procedures that grant judges increased discretion during a case); see also Steven S. Gensler, Judicial Case Management: Caught in the Crossfire, 60 DuKE L.J. 669, 674-88 (2010) (describing rules and legislative enactments that give judges a great deal of case-management discretion).

210 See Christopher M. Fairman, Heightened Pleading, 81 TEx. L. REv. 551, 567-90 (2002) (describing lower courts' efforts to forge substance-specific pleading requirements).

211 Marcus, supra note 206, at 404-09 (discussing legislatively created and substancespecific procedural reforms).

212 See, e.g., Burbank, Of Rules and Discretion, supra note 207, at 716-17 (arguing that civil rights cases might need special procedural rules to accommodate their distinctive attributes).

213 See Bone, Who Decides?, supra note 113, at 2006 (arguing that the Rules Advisory Committee is better positioned to determine which types of cases call for which types of procedural rules).

214 See Robert G. Bone, "To Encourage Settlement": Rule 68, Offers of Judgment, and the History of the Federal Rules of Civil Procedure, 102 Nw. U. L. REv. 1561, 1619 (2008) ("The idea that the Federal Rules of Civil Procedure should apply uniformly to all substantive law claims ... still has a strong hold on rulemaking today."). 
claims, will be vulnerable to different settlement-distorting forces and, thus, may call for different procedural mechanisms. Procedural reforms should be attentive to such distinctions and, more importantly, should provide courts with guidance regarding how and when to use particular tools.

Begin with the principle of uniformity. As one example, to the extent that cases generate substantial levels of variance-as may be true with, say, statutory claims implicating treble damages and penalties-the allocation of procedural entitlements should take into account the potentially distortive effect of that variance. In such instances, settlement pressure will be acute, so limited discovery at the pleading stage would generally be advisable to narrow the width of the potential settlement range and also to ensure that pleading-stage, merits-based evaluation neither underscreens the settlement pressure-generating claims nor overscreens them simply because of their potential to generate variance. Moreover, targeted discovery in cases that carry high levels of variance would ideally begin with discovery related only to the variance-generating claims-as it is those claims that are most likely to exert influence over parties' settlement decisions.

As another example, for cases characterized by pronounced informational asymmetries that advantage defendants, either a presumption in favor of limited discovery in conjunction with a plausibility pleading standard or, absent such discovery, a more permissive pleading standard is needed. Moreover, to reduce the number of costly and broad discovery requests made by uninformed plaintiffs in such cases, a targeted discovery plan should focus on unearthing facts, key search terms, and primary custodians of information related to the most critical issues first. For this subset of cases, discovery plans could be organized, to the extent possible, in a graduated fashion such that claimants can develop more specific discovery requests on those claims as they gather more relevant information. And depending on the complexity of the case, cases characterized by significant informational asymmetries should appropriately require defendants to organize produced materials to lead the court and the claimant to key facts (or the absence thereof) and to prevent the imposition of high search costs that would obscure those facts.

In addition, for the subset of relatively non-complex cases, which need very little discovery, if any ${ }^{215}$ (for instance, cases involving simple

215 Further empirical work is needed to determine the prevalence of these sorts of cases. One report, provided over ten years ago, indicated that a fair number of cases in federal 
breach of contract claims or claims arising out of a straightforward automobile accident), current rules permitting broad discovery and reforms aimed at mitigating the distortive effects of factors like cost imposition $^{216}$ and variance are not just largely unnecessary; they are also strategically exploitable for purposes of rendering claims economically prohibitive or driving settlement outcomes downward (or upward, to the extent they are deployed by a plaintiff). Accordingly, we should bear in mind that palliative rules for the distortive procedural warfare of complex cases may serve as barriers to entry for plaintiffs with low- or medium-value cases and as weapons for resource-advantaged parties in others.

Indeed, for these sorts of less complex cases-where the potential for non-merits factors such as cost imposition, variance, and informational asymmetries to distort settlements is also lowerprocedural mechanisms should, if anything, be simplified, particularly for cases that arise in areas in which the law is clear. Specifically, simplified or fast-tracked versions of the Federal Rules may well be in order. $^{217}$ This is particularly true if we seek to include in the system of public litigation-as I believe we should-these more "ordinary" cases. In fact, for these "ordinary" cases, rather than introduce new or additional procedures, reform efforts should instead be directed at eliminating the advantages enjoyed by repeat players who currently control electronic settlement databases, and toward informational equality by systematically requiring disclosure by both plaintiffs' and defense attorneys of basic settlement information attendant to these cases.

The need for procedural distinctions among cases with vastly different stakes and levels of complexity is not just a matter of ensuring access to justice. ${ }^{218}$ It is also a matter of bringing into the

court did not need discovery, but that in the cases that did have discovery, discovery costs accounted for ninety percent of litigants' costs. Memorandum from Judge Paul V. Niemeyer, Chair, Advisory Comm. on Civil Rules, to Judge Anthony J. Scirica, Chair, Comm. on Rules of Practice and Procedure (May 11, 1999); 192 F.R.D. 354, 357 (2000). However, both the data coverage and findings in that report have been questioned. See, e.g., Miller, From Conley, supra note 2, at 58 n.226. That said, given that there likely exists some subset of cases in which plenary discovery is unnecessary, it makes little sense to leave those cases vulnerable to the potential exploitation of discovery practices permitted by the Federal Rules.

216 See supra Part III.A.1.

217 Setting forth details of such potential tracks is the subject of future work, which would build on that of modern procedure thinkers along these lines. See, e.g., Burbank, Pleading, supra note 205, at 537-38, 545 (expressing support for the development of separate tracks for cases, depending on their underlying characteristics).

218 Indeed, there is a strong suspicion among scholars that complex, "Cadillac" procedures are pricing more modest cases involving low- or even medium-value claims out of the system. See Samuel Estreicher, Beyond Cadillacs and Rickshaws: Towards a Culture of 
system of litigation the public value of precedents, and perhaps, with adequate simplicity in these ordinary cases, the public value of trials, which could serve as informal bellwethers for settlements in more complex cases arising under similar liability theories. Such signals would also produce efficiency gains for the settlement market overall.

Beyond the principle of uniformity, different substantive claims warrant different procedural treatment as well. Different types of substantive claims are likely susceptible to different types of distortions, and as such, the problems attendant to the principle of uniformity apply equally to such substantive claims. In other words, abandoning the principle of uniformity will also lead to a weakening of the principle of transsubstantivity. ${ }^{219}$

More importantly, though, the principle of transsubstantivity is independently problematic because it forecloses considerationpotentially by Congress - of the importance of private enforcement through litigation to the substantive regulatory scheme in striking the appropriate balance between achievement of regulatory goals and mitigation of settlement-distorting forces. For example, some substantive claims-say, complex antitrust claims-systematically tend to require significant discovery and, under a transsubstantive regime, call for procedural mechanisms that stringently police the costs of such discovery. Substantive policy considerations, however, may warrant increased tolerance for the potentially distortive forces of costs or variance with respect to claims like employment discrimination which, as I have discussed in prior work, play an important role in an overall regulatory scheme. ${ }^{220}$ Where private litigants play a less crucial role in regulating harms, however, procedural mechanisms that mitigate the effects of costs and variance may be more desirable. In other words, procedural reform that rejects the principle of uniformity only gets us so far; in some instances, whether and to what extent to adopt certain reforms could depend on the particular substantive area of the law upon which such reforms would operate.

Citizen Service, 1 N.Y.U. J.L. \& Bus. 323, 325-27 (2005).

219 A point of clarification is in order. Consistent with the approach taken by scholars who have proposed substance-specific procedural reforms, it is not my argument that we should adopt entirely separate procedural regimes for every different body of substantive law. This is not a call, for instance, for a return to the common-law writ system. See, e.g., Stephen N. Subrin, The Limitations of Transsubstantive Procedure: An Essay on Adjusting the "One Size Fits All" Assumption, 87 DEnv. L. REv. 377, 388 (2010) ("Those who cherish transsubstantive procedure are right that we do not want to return to... the writ system ....").

220 See Glover, supra note 23, at 1449 (tracing how Congress relied in large part upon private litigation to enforce employment discrimination laws). 
As another example, there are certain substantive laws that tend systematically to generate low-value claims, and tend systematically to stem from alleged wrongdoing that occurred on a large scale. ${ }^{221}$ In such instances, there is a concern that defendants may exploit cost imposition to avoid liability as to any individual case, and thus to avoid liability in the aggregate, unless plaintiffs can bring their claims as a class or unless plaintiffs have access to other mechanisms that make low-value claiming economically viable. As I have explored in more detail in prior work, ${ }^{222}$ this is arguably the concern underlying recent cases invalidating class action waivers and the broader debate about the use of procedural private ordering to require arbitration and to prohibit the use of the class action device in cases involving these types of low-value claims. ${ }^{223}$

In these situations, there are two competing sources of settlement distortion: the variance generated by the certification of a class, on the one hand, and the strategic imposition of prohibitive costs through robust motions to dismiss and offensive plenary discovery practices on the other. To the extent that defendants' exculpation from liability is concerning, a number of nontranssubstantive, non-uniform procedural consequences follow. For example, the ability to prohibit the class action by contract-at least without providing adequate additional mechanisms to enable claiming ${ }^{224}$ - should be constrained for certain

221 For example, employment discrimination cases often concern low-value claims held by low-wage earners. See generally Michael Selmi, The Value of the EEOC: Reexamining the Agency's Role in Employment Discrimination Law, 57 Oніо ST. L.J. 1, 32-40 (1996) (noting that the vast majority of race and gender discrimination cases brought by the Equal Employment Opportunity Commission involved low-value claims and often featured lowwage earners as plaintiffs).

222 J. Maria Glover, Beyond Unconscionability: Class Action Waivers and Mandatory Arbitration Agreements, 59 VAND. L. REV. 1735, 1740-47 (2006) (describing how the prevalence of contracts of adhesion provides an increasingly greater opportunity for class action waivers to effectively prohibit low-value claims).

223 See id. at 1761 (describing how class action waivers undermine the central justifications for giving arbitration a favored status).

224 Such mechanisms began appearing in what are known as "third-generation" arbitration clauses. For example, AT\&T implemented such an arbitration clause in 2006, which "allocates the entire cost of arbitration [on meritorious claims] to [the defendant]"; "permits either party to proceed in small claims court"; "contains no ... limitation on the arbitrator's authority to award punitive damages"; "provides for a minimum award (denominated a 'premium') if the arbitrator awards the customer more than the amount of [the defendant's] last settlement offer"; and provides that the defendant will "pay [the customer's] attorney, if any, twice the amount of attorneys' fees, and reimburse any expenses." Brief of AT\&T Mobility LLC as Amicus Curiae in Support of Neither Party at 1416, T-Mobile USA, Inc. v. Laster, 553 U.S. 1064 (2008) (No. 07-976). Such mechanisms come with their own problems, see Glover, supra note 23 , at 1166-67, but they are certainly better than the alternative: no mechanisms to enable claiming and no class action device. At the very least, courts should insist that some of these mechanisms be in place in order for 
subsets of substantive rights that tend to generate low-value claims and for which enforcement by private parties is needed to deter wrongdoing. For instance, this measure might be warranted in cases involving claims like those brought under the Fair Labor Standards Act (FLSA) for wage-and-hour violations-claims that are of typically small value for any given individual and that are brought under a statute characterized by significant levels of under-enforcement by the relevant public regulatory body. ${ }^{225}$ Further, and putting aside for the moment the issue of contractual class action prohibitions, the requirements of Rule 23 may well warrant relaxation in such cases, perhaps after a more robust, factually informed analysis of the claims' merits prior to that relaxed certification analysis.

Conversely, and given the unique ability of class certification to generate high levels of variance for substantive areas of the law not typified by a tendency to generate low-value claims, the strictures of Rule 23 might warrant tightening if a preliminary, factually informed analysis of the merits indicates that the underlying claims are weak. Alternatively, or in addition, class certification could be granted conditionally in such cases, with the ultimate decision about certification dependent upon a further showing, after a limited period of discovery, of a greater likelihood of success on the merits. Indeed, such reforms could well mitigate the Court's concerns in Twombly about permitting access to significant discovery cost imposition and about the high level of variance generated by the certification of a class. ${ }^{226}$ Such reforms would also address concerns, voiced by Twombly's critics, that defendants likely possessed the information relevant to plaintiffs' allegations of conspiracy under the Sherman Act. ${ }^{27}$ Specifically, as one example, such reforms would have permitted the Twombly plaintiffs to obtain limited preliminary discovery regarding the alleged existence of an agreement by defendants to violate the antitrust laws, while providing a mechanism for more robust evaluation of the plausibility of plaintiffs' claims before they could obtain class certification and proceed further in the litigation.

To say that the foundational principles of uniformity and

\footnotetext{
contracts containing class waivers to survive an unconscionability analysis.

225 Glover, supra note 23, at 1150-51.

226 As I have explored in prior work, a stricter approach to class certification in cases alleging antitrust conspiracy is less concerning as a matter of overall regulation of such misconduct, given fairly robust public enforcement of antitrust violations. Glover, supra note 23, at 1158-59 (discussing the Department of Justice's amnesty program for whistleblowers reporting Sherman Act violations).

227 See Bone, Regulation of Court Access, supra note 6, at 919-20 ("[T]he defendant [in Twombly had] a great deal of information relevant to liability and the plaintiff [had] very little....").
} 
transsubstantivity must be revisited is not to advocate that reform should occur primarily through the ad hoc and burdensome case-bycase exercise of judicial discretion. There are a number of architectural challenges to mediating among these various concerns. These challenges are best addressed by the Advisory Committee, ${ }^{228}$ which can commission broad-based empirical studies, and which can then craft procedural rules that channel judges' discretion through the inclusion of as much concrete guidance on these issues as possible. Moreover, in some instances, particularly those in which countervailing distortions exist-for example, claims that generate variance on the one hand but are susceptible to cost exploitation by defendants against plaintiffs with small-value claims on the other-Congress may need to make substantive policy judgments, as it has done before in limited contexts. ${ }^{229}$ Indeed, Congress is perhaps best positioned to determine whether-as a matter of the enforcement of the underlying substantive law in light of overall regulatory objectives, ${ }^{230}$ as a matter of access to justice, ${ }^{231}$ or as a matter of the "moral weight" which one might attach to certain substantive rights ${ }^{232}$-it is better to permit a little more variance through, say, class certification, than it is to leave such claims unremedied. Once these first-order determinations are made, judicial discretion regarding the particulars of a given case would proceed more predictably and systematically.

All of the potential reforms set forth above necessarily warrant more exhaustive consideration than can be provided here. They are offered here as examples of reforms that should be part of the redesign of current procedural rules for a world of settlement. Further, they lay the groundwork for the development of procedural tools that would break free from the underlying principles of the Federal Rules (which are ill-suited to a world of settlement) would address the factors

228 Bone, Who Decides?, supra note 113, at 1963 (arguing that trial judges face serious problems in tailoring case-specific procedures that work well in the highly strategic environment of litigation).

229 See Stephen B. Burbank, The Class Action Fairness Act of 2005 in Historical Context: A Preliminary View, 156 U. PA. L. Rev. 1439, 1530 n.365 (2008) (citing the Truth in Lending Class Action Relief Act of 1995, Pub. L. No. 104-12, 109 Stat. 161 (codified as amended at 15 U.S.C. $§ 1640$ (2006))).

230 See Glover, supra note 23, at 1146-52 (describing Congress's position in assessing public and private enforcement mechanisms to obtain its enforcement objectives).

231 See Glover, supra note 222, at 1736-37 (arguing that class action waivers, in certain substantive contexts, may effectively prevent broad swaths of potential plaintiffs from vindicating substantive rights and may effectively enable defendants to avoid liability under certain statutes).

232 See Bone, Regulation of Court Access, supra note 6, at 914 ("Many people assign substantial moral weight to constitutionally protected interests, including, and perhaps especially, the interests protected by the First Amendment."). 
tending to unmoor those settlements from the merits of underlying disputes, and would direct pretrial procedures more purposefully toward generating merits-based information relevant to parties' settlement decisions. In short, they pave the way toward procedures designed for a world of settlement.

\section{B. A New Vision of Procedures Designed for a World of Settlement}

From the challenges issued above, as well as from the examples of reform proposals situated therein, a new vision for a system of procedure in a world of settlement emerges. At a conceptual level, rethinking the assumptions identified above and moving toward reform require, fundamentally, a redefining of the relationship between procedure-in particular, pretrial procedure-and guidance regarding the substantive merits of a given case. Whereas under the current rules, pretrial procedure is viewed largely as separate from, and antecedent to, robust examination of the merits, in a world of settlement, merits evaluation and pretrial procedure must be both temporally interconnected and operationally interdependent.

More specifically, a new system of procedure should harness pretrial procedural mechanisms to provide meaningful merits-based guidance for settlement decisions and to address the distortive effects of external forces on those decisions. Moreover, merits-based guidance generated through pretrial procedures should influence parties' access to procedural mechanisms. In short, procedural reform should foster, rather than merely avoid interfering with, the fundamental goal of our litigation system-to align case outcomes with the dictates of substantive law. ${ }^{233}$

This new vision has broader implications for the world of modern litigation. First, it calls for a partial retreat from the highly discretionary, nontransparent, and unbounded forms of managerial judging that have dominated the litigation landscape in the past

233 At some level, this new vision of procedure requires rethinking the 1938 reformers' "hands off" procedural approach. First, this "hands off" approach perpetuates a fiction; scholars have long recognized that procedure significantly impacts the functioning of substantive law. See, e.g., Thomas O. Main, The Procedural Foundation of Substantive Law, 87 WASH. U. L. REV. 801, 802 (2009) ("Procedure is an instrument of power that can, in a very practical sense, generate or undermine substantive rights."); Stephen B. Burbank \& Tobias Barrington Wolff, Redeeming the Missed Opportunities of Shady Grove 30 (Univ. of Pa. Law Sch. Pub. Law \& Legal Theory Research Paper Series, Research Paper No. 10-31, 2010), available at http://papers.ssrn.com/sol3/papers.cfm?abstract_id=1677608. Second, the "hands off" approach stands as an impediment to meaningful reform: Procedure cannot simply be viewed as a potential problem; rather, it must also be viewed as part of the solution. 
decades.234 Procedural reforms along the lines suggested above provide for a more robust adjudicative and transparent role for judges during the pretrial phase of litigation. Moreover, they direct the exercise of judicial discretion under those procedural rules explicitly, and more concretely, toward guiding parties' settlement decisions with merits-based considerations.

Second, and relatedly, evaluation of the merits prior to settlement, even in a non-case-dispositive setting, would reinvigorate the public dimension of private litigation ${ }^{235}$ by promoting an increase in judicial pronouncements of the law. Such pronouncements would help resolve existing legal uncertainties and add transparency to a system of litigation dominated by settlement. Further, public pronouncements of the law in one case hold promise to orient parties' litigation and settlement decisions around merits-based considerations in future cases.

Third, this new vision of procedure calls for institutional commitments to the fundamental precept that our procedural system should aid in the effectuation of substantive law. Introducing more robust pretrial evaluation of case merits may well require additional institutional resources. ${ }^{236}$ At the same time, there is reason for some optimism that these additional resource demands would be tempered by efficiencies that reform would also create. For example, redesign of the Federal Rules for a world of settlement-and in particular, redesign that includes mechanisms that provide concrete and explicit guidance to judges in performing pretrial tasks-may well redirect the resources currently devoted to managerial tasks. Further, appropriate reforms would help narrow parties' settlement ranges in a given case and therefore promote settlements more quickly, and moreover, could generate merits-based information that would guide parties in future, similar cases-both of which could reduce demands on the judicial

234 See, e.g., Gensler, supra note 209, at 720 (describing how the Federal Rules have continued to rely heavily on a "tradition of discretion"). The notion of highly discretionary judging has deeper roots vis-à-vis the Federal Rules, as it "lay at the heart of Pound's jurisprudence." Tidmarsh, supra note 1, at 521.

235 See generally Fiss, supra note 5, at 1085 ("[The job of the judicial official is to] explicate and give force to the values embodied in authoritative texts such as the Constitution and statutes: to interpret those values and to bring reality into accord with them.").

236 Such additional resources could well come in the form of court-annexed arbitrators, mediators, or subject-matter-expert special masters, whose discretion to perform pretrial tasks should ideally be bounded by the reforms set forth herein. Such arrangements give rise to a number of questions regarding, for instance, institutional competence, mechanical operation, and-more broadly - the appropriate theoretical and normative underpinnings of alternative dispute resolution mechanisms more generally. Such questions are for another day. 
system. Finally, in implementing reforms, Congress and the Advisory Committee should consider whether some of the additional pretrial tasks suggested here, perhaps including the management of targeted discovery, could be entrusted to special masters, magistrate judges, or other judicial officers whose role it would be to aid judges and parties in the pretrial process.

This Article poses a foundational challenge to the current design of our Federal Rules of Civil Procedure. And without doubt, enacting a new set of procedures for a world of settlement will not be without its costs. However, the costs of redesign cannot be considered in a vacuum. Ultimately, any costs of reform must be weighed against the costs of current procedures to parties, judges, and the civil justice system overall-costs that are exceedingly high and frequently distortive of settlement outcomes. Indeed, the merits-related "goods" generated by current pretrial procedures-specifically, cursory meritsbased signals-are frequently dwarfed by the impact of various nonmerits factors on settlement outcomes. Given the faint shadow these signals cast, these "goods" may not be worth their high price. Finally, the current procedural system comes at a substantial cost to our system of litigation because it fails meaningfully to achieve its own purported foundational goals. These social costs cannot be ignored. Reform is needed to ensure that the content of substantive law, and not an arbitrary and distorted settlement "market price," orders behavior, deters misconduct, and makes victims of wrongdoing whole. The costs associated with careful redesign of our procedural system to better achieve these goals and to meet the demands of a world of settlement may thus be well worth it.

\section{CONCLUSION}

The world of settlement is here to stay, and it is time to face it head-on. The Federal Rules of Civil Procedure, designed for a bygone world of trials, are increasingly unable to fulfill their animating goal that cases be resolved on their merits, as defined by the governing substantive law. Procedural reform is needed to grapple with the unique difficulties generated by settlement as the dominant form of case resolution in achieving this objective.

This Article has laid the groundwork for designing a new procedural regime by challenging foundational assumptions of the Federal Rules that no longer hold in a world of settlement, and by offering reforms that break free from these underlying tenets. It has also presented a new vision for our procedural system that expressly integrates pretrial procedure with meaningful merits-based 
determinations. In offering this new vision of procedure, this Article seeks both to invite further exploration of avenues of procedural redesign and to guide the way for needed empirical work on such reforms. Meaningful and effective reform will not come quickly or easily, but ultimately, such reform ought to come. 